\title{
THE IMPORTANCE OF WATER ACCUMULATION OF SNOW COVER MEASUREMENTS IN MOUNTAINOUS REGIONS OF SLOVENIA
}

POMEN MERITEV VODNATOSTI SNEŽNE ODEJE V SLOVENSKIH GORSKIH POKRAJINAH

Matej Ogrin, Jaka Ortar

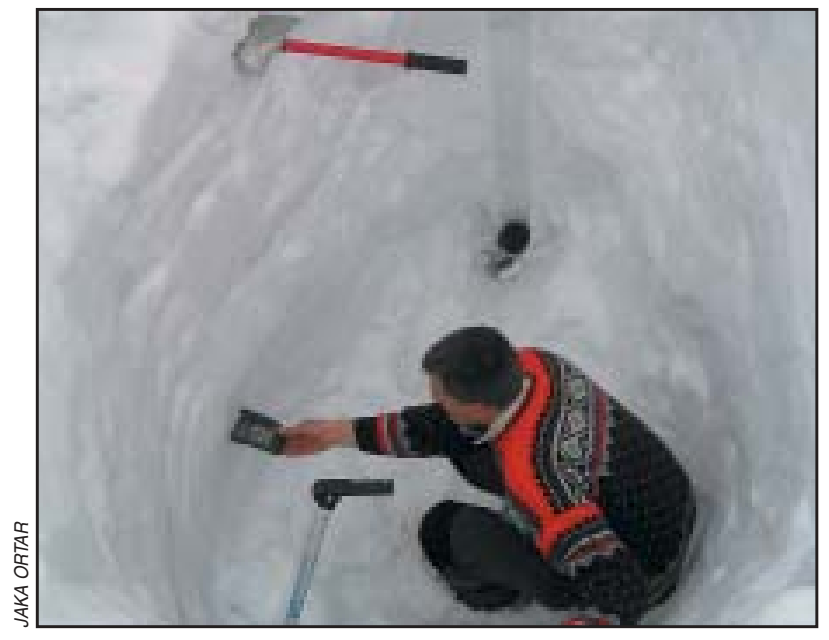

Preučevanje debele snežne odeje na Soriški planini.

Studying of deep snow cover in Soriška planina alp.

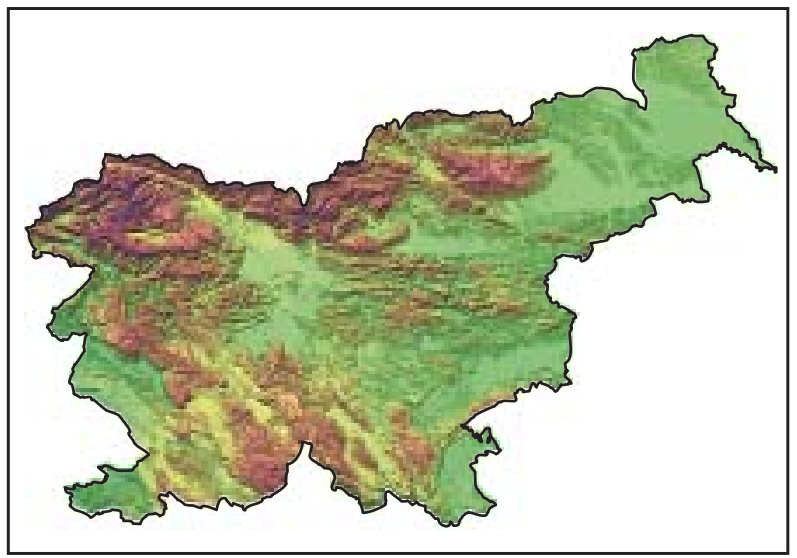




\section{The importance of water accumulation of snow cover measurements in mountainous regions of Slovenia}

UDC: $911.2: 551.578 .4(497.452)$

COBISS: 1.01

ABSTRACT: Snow cover is a frequent phenomenon in Slovenia and even in the lowlands of the interior regions, it can last for several weeks. The properties of snow and winter weather after the snow cover has formed, determine the load of snow upon houses, trees and other objects. Water accumulation of snow cover (WASC) gives us the amount of water in snow and therefore also the weight of snow. Deep snow cover can soak its own melting water from the surface, so WASC does not decrease as fast as one would conclude from the intensity of melting. WASC is also a good indicator of winter precipitation where precipitation stations are rare and precipitation gradients are big. The researches carried out in the winter 2005/2006 showed that precipitation in the central part of the Bohinj ridge in the Slovenian Julian Alps, was about $50 \%$ higher than at its northern edge, where the meteorological station Vogel is located.

KEYWORDS: snow cover, water accumulation of snow cover, weight of snow, Upper Sava valley, Bohinj ridge

The article was submitted for publication on June 30, 2006.

\section{ADRESSES:}

Matej Ogrin, Ph. D.

Department of Geography

Faculty of Arts, University of Ljubljana

Aškerčeva cesta 2, SI - 1000 Ljubljana, Slovenia

E mail: Matej.Ogrin@siol.net

\section{Jaka Ortar, student}

Department of Geography

Faculty of Arts, University of Ljubljana

Aškerčeva cesta 2, SI - 1000 Ljubljana, Slovenia

Email: ortosplet@gmail.com

\section{Contents}

1 Introduction

2 The method of measuring water accumulation of snow cover (WASC)

3 WASC and capability of snow to soak rain water or melting water

3.1 Measurements in Vodice near Ljubljana 51

3.2 Snow weight in the Upper Sava valley 52

$4 \quad$ WASC as an indicator of precipitation in mountains

4.1 WASC on the Bohinj ridge 56

5 Conclusion 60

6 References 60 


\section{Introduction}

Snow cover forms during snowing when the surface temperature falls to $0^{\circ} \mathrm{C}$ or less. Then snow flakes do not melt any more. Snow flakes have many shapes, like real crystals, or like other irregular shapes. At very heavy snowfall, the surface temperature can be even a little above the freezing point. In such cases the snow flakes on the surface melt slower than the new ones are falling, which leads to the formation of snow cover.

Snow consists of one or more layers and layers consist of parts of snowflakes and the air among them. Most snowflakes deform when they fall on the surface because dendrites break and separate from the main part. Even if reaching the surface in one piece, many snowflakes deform under compression and sinking processes in the snow cover. We see that snow crystals or their parts and the air among them are the main components of snow cover. Besides, in snow there can be also water. Therefore, the volume of snow cover is not a sum of snowflake volumes. It is a sum of the volumes of snowflakes and their parts, water drops and the air trapped among them. Even after snowing, the volume of snow cover changes constantly, the reason for this being the sinking of snow. If temperatures are above $0^{\circ} \mathrm{C}$, melting must be considered as well.

With time, snow cover transforms. Snow crystals change their form into grains (Šegula 1986). This process depends on air temperature. The bigger the daily amplitudes are, the faster the grains form. Old snow cover consists only of grains, which are usually well seen.

Melting occurs at temperatures above $0^{\circ} \mathrm{C}$. However, it depends very much also on air humidity and some radiative properties of the atmosphere. When the air is humid and the sky is cloudy, snow melts faster than when the air is dry and the sky is clear. It can be often seen in shady spots that despite temperatures above $0^{\circ} \mathrm{C}$, snow remains frozen or dry on its surface. This is due to evaporation of snow cover. During this process $2,8 \mathrm{MJ}$ of latent heat are taken from the snow cover to evaporate $1 \mathrm{~kg}$ of water. Due to evaporation the temperature of snow surface on such days is mainly negative, so only little water evaporates from snow. In fact, in winter time, this amount is negligible.

\section{The method of measuring water accumulation of snow cover (WASC)}

WASC gives us the amount of water in snow cover. This information is useful for estimating snow weight on objects. It represents millimeters $(\mathrm{mm})$ of water which we would get if all the snow melted and if no melted water ran off. The measuring of WASC must be done at an appropriate spot. The surface must be flat and far enough from obstacles, such as vegetation, buildings, rocks, etc. On the measuring spot there must not be sources of heat and there should be no effects of wind erosion or accumulation. And finally, it is necessary that the measuring spot is out of reach of snow avalanches (Vrhovec 2000; Sluga 2000; Ogrin 2005b).

In Slovenia, WASC is measured at the meteorological stations Bilje near Nova Gorica, Celje, Kredarica, Maribor airport, Ljubljana Bežigrad, Murska Sobota, Novo mesto, Rateče and Šmartno near Slovenj Gradec. Among the mountainous stations such measurements are taken yearly only on Kredarica. In the past some measurements were taken also on the Komna and Vogel (ARSO 2006).

Measurements in the lowlands are relatively easy and accurate. If done correctly, such a measurement can be even more precise than precipitation measurements with a pluviometer. Namely, snow gathers on the edges of a pluviometer and it is very hard to distinguish which part of snow on the edge will fall into a pluviometer and which one not. In the Slovenian lowlands, except in karst-dinaridic regions and in some parts of northeastern Slovenia, strong winds during snowing are rare. Consequently, snow cover accumulates equally and snow depth rarely exceeds $50 \mathrm{~cm}$. This makes the measuring even easier, because it can be done with an about $60 \mathrm{~cm}$ long tube or pot, which is pushed into the snow vertically, upside down, with the closed side at the top. Small errors occur when separating the snow from the surface, but they can be diminished if the surface is smooth. However, circumstances in the mountains differ from those in the lowlands. Winds are stronger and more frequent, which in many spots causes erosion and accumulation of snow. There is also not a lot of flat surface, so in many places the measuring of snow can not be carried out. Different conditions in the mountains are usually the reason for bigger errors. Due to a very 
small share of flat terrain, the data on snow depth, even if measured correctly, give us different information about snow conditions in the mountains. Namely, on slopes snow accumulates differently.

In the previous studies, every layer of snow cover was measured separately (Ogrin 2005b). Total WASC was a sum of WASC of each layer. A cylinder with a length of $10,8 \mathrm{~cm}$ and a diameter of $2,25 \mathrm{~cm}$ was used for sampling snow layers. Snow density of each layer was calculated. Even if a layer was higher than the cylinder, it was assumed that the snow structure within the layer does not differ. Layers were defined by a different structure of snow. Such measurements were taken in each layer. The advantage of this method is the insight into properties of each layer. On the other hand, the disadvantage is a bigger error, because at each sampling some errors are inevitable. In the winter 2005/2006 we decided to use the method of taking one sample through the whole snow profile. A 1,5 m long tube was vertically pushed into the snow. At the bottom, an obstacle was set to prevent the snow from falling out of the tube. The snow in the tube was put into plastic bags and afterwards into a pot where it was melted and the melted water was weighed. The sample of snow could be simply measured in the field but the scales available were not precise enough to weigh such a big amount of snow. The loss of mass due to evaporation of melting water was prevented by covering the pots. From the difference in mass of dry and wet bags, we also calculated the amount of melting water left on plastic bags. If snow cover was deeper than the length of the tube, the sampling was repeated until the ground was reached. Using this method of sampling through more layers, most of the error from the previous studies was excluded. The time of sampling was reduced as well.

A comparison of both methods was made. We assumed that the method of sampling through more layers (a tube method) more accurate and that all the differences between the methods come from the errors of the method where each layer was measured (a cylinder method). The first comparison was made in January 2005 in the Planica valley in the Slovenian Julian Alps, and the second in the Pod Špik cirque in February 2005.

According to the results of the tube method the WASC was $160 \mathrm{~mm}$ and $311 \mathrm{~mm}$ respectively.

The cylinder method was tested with three different samples:

Sample 1: $\mathrm{r}_{1}=3,95 \mathrm{~cm}, \mathrm{~h}_{1}=9,9 \mathrm{~cm}$, metal;

Sample 2: $\mathrm{r}_{2}=2,25 \mathrm{~cm}, \mathrm{~h}_{2}=10,8 \mathrm{~cm}$, plastic;

Sample 3: $\mathrm{r}_{3}=3,5 \mathrm{~cm}, \mathrm{~h}_{3}=10,1 \mathrm{~cm}$, plastic.

The sample 3 was excluded due to sampling problems during the measurement. Some layers were too thin to get quality samples.

Table 1: The comparison of tube and cylinder method. It is assumed that errors occurring at tube method are negligible.

\begin{tabular}{lccc}
\hline & WASC in mm & Difference (mm) & Difference (\%) \\
\hline The Planica valley, 29 January 2005 & & & \\
Tube & 160 & 24 & 15,0 \\
Sample 1 & 184 & 25 & 15,6 \\
Sample 2 & 185 & & \\
\hline Pod Špikom, 3 February 2005 & 311 & 12 & 4,2 \\
Tube & 323 & 2 & 0,6 \\
Sample 1 & 313 & & \\
Sample 2 & &
\end{tabular}

Table 1 shows differences occurring when measuring WASC with a cylinder method comparing to a tube method. The differences in the Planica valley are 15 and 15,6\%, while in the second test they fell to 4,2 and $0,6 \%$ respectively. The differences differ according to the time and spot of sampling, and can be explained with different snow conditions. In the Planica valley, the snow cover was $65 \mathrm{~cm}$ deep and formed out of 5 layers, while in the cirque Pod Špik the snow cover was $110 \mathrm{~cm}$ deep and formed out of 7 layers. Differences are usually bigger in thinner snow cover with thinner layers. Errors are influenced also by the structure of snow. Hard layers or layers where snow crystals are dry, formed as grains and not connected with each other, cause bigger differences as well. 


\section{WASC and the capability of snow to soak rain water or melting water}

Snow cower melts on the surface or at the junction with the ground underneath. Most of the melting water from the surface runs through snow cover towards the ground, while a very small part of it evaporates. In winter time evaporation can be neglected. A part of melting water always stays within the snow and fills the space between crystals, no matter how deep the snow cover is.

If snow cover is deep and if its inside temperature is bellow $0^{\circ} \mathrm{C}$, the melting water, which runs through snow, freezes. Therefore the snow cover is thinner, but its density is bigger and WASC remains the same. Similar can happen when it rains. Then the water entering the snow cover is a mixture of rain water and melting water. But, if snow cover is deep enough so that there is no run off or if the run off is smaller than the rain water, then WASC increases. The depth of snow which can hold most of the melting and the rain water is a function of the amount of the entering water, snow temperature and snow structure. New, dense snow can soak more water than old or very light snow. When the entering water freezes, the melting heat warms the snow cover up to $0^{\circ} \mathrm{C}$. When the whole snow profile is warmed up to $0{ }^{\circ} \mathrm{C}$, the water cannot freeze any more. It stays in a liquid form within snow, until snow is totally saturated. At this point, snow can soak no additional water. The soakage of snow cover is an important factor that influences the quality of snow cover and therefore its density and duration. The bigger the snow density is, the more resistant the snow is. Namely, more snow crystals have to melt, which takes more melting heat.

So, if the water which enters and stays in the snow, comes from rain, snow gets additional mass, which, after freezing, could be considered as an addition of ice crystals within the snow. The soaking of rain and the additional mass in snow cover could be very important factors when dealing with the loading of buildings due to snow.

\subsection{Measurements in Vodice near Ljubljana}

The following example indicates how much water snow cover soaked during rainfall which appeared right after heavy snowfall. The data were collected while researching the snow cover in Vodice near Ljubljana, $345 \mathrm{~m}$ a s 1 , measured by a meteorologist G. Vertačnik at his private meteorological station. On 26 November 2005, at 14:15 after about 21 hours of heavy snowfall, the snow cover was $40 \mathrm{~cm}$ deep. The snow was heavy and wet, with WASC $48 \mathrm{~mm}$. About an hour after this measurement, the snow changed into rain. Rain kept falling during the rest of the afternoon and the whole night on 27 November. In the morning, at 7 o'clock, $36 \mathrm{~mm}$ of precipitation were measured since $14: 15$ on November 26 . The air temperature was on both days between 0 and $2{ }^{\circ} \mathrm{C}$.

Table 2: The changes in the properties of snow cover before and after the rain from 26 to 27 November 2005 (Vertačnik, 2006).

\begin{tabular}{lcccc}
\hline $\begin{array}{l}\text { Date and time } \\
\text { of measurement }\end{array}$ & $\begin{array}{c}\text { Date and time } \\
\text { of measurement }\end{array}$ & $\begin{array}{c}\text { Date and time } \\
\text { of measurement }\end{array}$ & $\begin{array}{c}\text { Date and time } \\
\text { of measurement }\end{array}$ & $\begin{array}{c}\text { Date and time } \\
\text { of measurement }\end{array}$ \\
\hline $\begin{array}{l}26.11 .2006,14: 15 \\
27.11 .2006,7: 00\end{array}$ & 40 & 48 & 120 & Between the measurements $36 \mathrm{~mm}$ \\
& 24 & 53 & 221 & $\begin{array}{c}\text { of precipitation fell, } 4 \mathrm{~mm} \text { as snow } \\
\text { and 32 mm as rain. }\end{array}$ \\
\hline
\end{tabular}

About 32 out of $36 \mathrm{~mm}$ fell as rain and the rest $4 \mathrm{~mm}$ as snow. However, it is almost impossible to determine the exact amount of snow or rain from precipitation, because snow was changing into rain for some time. Since the air temperature was positive, the snow was melting. In addition, snow was melting also due to the falling rain. In the morning on 27 November, snow cover was still $24 \mathrm{~cm}$ deep, which is $60 \%$ of the depth measured in the previous afternoon. But the WASC was $53 \mathrm{~mm}$, which is $5 \mathrm{~mm}$ more than before the rain started to fall. It can be seen that out of $32 \mathrm{~mm}$ of rain and $4 \mathrm{~mm}$ of snow during the afternoon and the night, $31 \mathrm{~mm}$ ran off and $5 \mathrm{~mm}$ remained in the snow cover. Even if all the $4 \mathrm{~mm}$ of snow, which fell as snow, retained, at least $1 \mathrm{~mm}$ out of 32 would have to stay within the snow cover. But 
the snow was melting most of the time, so we can see that the snow cover soaked more rain. Measurements showed that despite the shrinking (from 40 to $24 \mathrm{~cm}$ ) and the melting of snow cover from 26 November to 27 November, the WASC grew. The density rose from 120 to $220 \mathrm{~kg} / \mathrm{m}^{3}$. So the weight of snow, after 12 hours of rain at positive temperatures, was bigger than before the rain.

Another measurement was taken at the same place about a month later. On the last days of December 2005, from 26 December to 29 December $44 \mathrm{~cm}$ of snow with WASC $35 \mathrm{~mm}$ fell during occasional snowfalls. Thus the density was $79 \mathrm{~kg} / \mathrm{m}^{3}$. Afterwards, until 6 January 2006, additional $29 \mathrm{~mm}$ of precipitation fell as rain and $16 \mathrm{~mm}$ as snow. On 8 January, WASC was $57 \mathrm{~mm} \pm 3 \mathrm{~mm}$ and the depth of snow was $23 \mathrm{~cm}$. The density increased to $248 \mathrm{~kg} / \mathrm{m}^{3}$ and WASC was $57 \mathrm{~mm}$, which is why the weight of snow was $57 \mathrm{~kg} / \mathrm{m}^{2}$. Air temperatures between 1 and 8 January were between $-3,6$ and 2,6 ${ }^{\circ} \mathrm{C}$ (Vertačnik 2006). If we presume that no snow melted and ran out of the snow cover, we see that at least $6 \mathrm{~mm}$ of rain remained in the snow cover. Namely, if we sum up only the snow precipitation, we get $51 \mathrm{~mm}(35 \mathrm{~mm}+16 \mathrm{~mm})$. For each $\mathrm{mm}$ of snow which melted and ran out, we get an additional $\mathrm{mm}$ of rain that remained within the snow.

Table 3: The changes in the properties of the snow cover between 29.12. 2005 and 8.1.2006.

\begin{tabular}{|c|c|c|c|c|}
\hline $\begin{array}{l}\text { Date and time } \\
\text { of measurement }\end{array}$ & $\begin{array}{l}\text { Date and time } \\
\text { of measurement }\end{array}$ & $\begin{array}{l}\text { Date and time } \\
\text { of measurement }\end{array}$ & $\begin{array}{l}\text { Date and time } \\
\text { of measurement }\end{array}$ & $\begin{array}{l}\text { Date and time } \\
\text { of measurement }\end{array}$ \\
\hline 29. 12.2005, 21:00 & 44 & 35 & 79 & \\
\hline 8.1.2006, evening & 23 & 57 & 248 & $\begin{array}{l}\text { Between measurements } 45 \mathrm{~mm} \\
\text { of precipitation fell, } 16 \mathrm{~mm} \text { as snow } \\
\text { and } 29 \mathrm{~mm} \text { as rain. }\end{array}$ \\
\hline
\end{tabular}

\subsection{Snow weight in the Upper Sava valley}

The described examples showed that snow cover soaks some of the rain or its own melting water. Similar happened in the Upper Sava valley in December 2006. Snow cover began to form in the valley on 23 November, but until 24 November, only $3 \mathrm{~cm}$ of snow fell. On 25 November, heavy snowfall began and it did not stop for about 40 hours. At the meteorological station Rateče, $865 \mathrm{~m}$ a s 1 , the snow depth at the end of snowing was $92 \mathrm{~cm}$, and in Gozd Martuljek, $10 \mathrm{~km}$ eastward down the valley, there were $89 \mathrm{~cm}$ of snow (ARSO 2006; Ogrin 2005a) Two days later another snowfall left $22 \mathrm{~cm}$ of snow in Rateče, where on 30 November the snow depth was $103 \mathrm{~cm}$, with the WASC of $106 \mathrm{~mm}$ and the density of $103 \mathrm{~kg} / \mathrm{m}^{3}$. Another north Mediterranean cyclone brought precipitation to Slovenia in the evening on 2 December. Only at the beginning, the snow fell under $1000 \mathrm{~m}$ a s 1 , but during the night on 3 December, the snow changed into rain under $1000 \mathrm{~m}$. In the Upper Sava valley, the snow line was between 800 and $1100 \mathrm{~m}$, depending on the intensity of precipitation. In the evening on 3 December, rain and snow in the Upper Sava valley stopped. In Rateče $38 \mathrm{~mm}$ of precipitation fell, $4 \mathrm{~cm}$ of it as snow. At the beginning only $1 \mathrm{~cm}$ fell as snow. During the night it started to rain, and towards the noon on 3 December, the snow began to mix with rain. In the afternoon there was more and more snow and less rain. Before the end of the precipitation, snow prevailed and additional $3 \mathrm{~cm}$ fell. During the precipitation the temperature was between 0 and $2{ }^{\circ} \mathrm{C}$. Until 7 December, occasionally still some precipitation occurred. In Rateče $24,5 \mathrm{~mm}$ of precipitation fell, most of it as snow $(16 \mathrm{~cm})$, and only a small part as rain. In the evening on 7 December, the snow depth in Rateče was $63 \mathrm{~cm}$. From 7 December to 26 December dry and cold weather prevailed, so the melting of the snow cover was negligible. In Rateče, the mean December temperature was $-5,7^{\circ} \mathrm{C}$, the maximum temperature $3,6^{\circ} \mathrm{C}$ and the minimum temperature $-17,9^{\circ} \mathrm{C}$. On 26 December, the snow depth in Rateče was still $60 \mathrm{~cm}$. Since the last precipitation, the snow cover sank for $3 \mathrm{~cm}$, and no water ran out of snow.

From 26 December to 8 January, several snow falls left altogether $141 \mathrm{~cm}$ of new snow, which sunk intensively, the reason for this being its low density. The highest snow depth, $125 \mathrm{~cm}$, was on 2 January. However, when dry weather began on 7 January, the snow cover was $105 \mathrm{~cm}$ deep. From that day and to mid February, dry and cold weather prevailed (ARSO 2006). 
Table 4: Snow cover properties in Gozd Martuljek on 22nd January 2006.

\begin{tabular}{lcccc}
\hline Date & Snow depth $(\mathrm{cm})$ & WASC $(\mathrm{mm})$ & Snow weight $\left(\mathrm{kg} / \mathrm{m}^{2}\right)$ & Snow density $\left(\mathrm{kg} / \mathrm{m}^{3}\right)$ \\
\hline 22.1 .2006 & 80 & 233 & 233 & 291 \\
\hline
\end{tabular}

On 22 January 2006 WASC was measured in Gozd Martuljek. $80 \mathrm{~cm}$ of snow had the density of $291 \mathrm{~kg} / \mathrm{m}^{3}$ and the WASC of $233 \mathrm{~mm}$. The snow weight was $233 \mathrm{~kg} / \mathrm{m}^{2}$. We did not carry out a test of WASC in Rateče but we presume, that precipitation in Gozd Martuljek ( $750 \mathrm{~mm}$ a s 1), $10 \mathrm{~km}$ eastward from Rateče, was not much different than in Rateče. It is estimated that precipitation was about the same, although small differences (less than 10\%) can appear.

Since 23 November precipitation in Rateče was $253 \mathrm{~mm}$. The difference between the WASC in the Gozd Martuljek and the precipitation in Rateče is $20 \mathrm{~mm}$, and is mainly a result of different precipitation between the two locations and not a result of the water run off. During the bad weather in Gozd Martuljek from 2 to 3 December after the first hours of snowing, rain prevailed most of the day. Nevertheless, after testing the snow we saw that about $15 \mathrm{~cm}$ under the top of the snow cover, the interior snow was still dry most of the day, which shows that the majority of rain remained in the upper layer of the deep snow cover. Most of the rain remained in the upper layer on the old snow cover, where about $2 \mathrm{~cm}$ of the new snow were mixed with rain water.

In this winter period, the snow depth was decreasing and increasing. However, the WASC was increasing from one precipitation to another and in the valley people began to throw snow from the roofs of the buildings because of the danger that snow would break the roofs. Although the snow cover was not deep (in this period it was never deeper than $124 \mathrm{~cm}$ ), the weight of snow was relatively high. The reason for this was high snow density, which was a result of the rain in December, which sunk the snow and increased the WASC. Usually, snow density during snowing at negative temperatures does not exceed $80 \mathrm{~kg} / \mathrm{m}^{3}$. To achieve the same snow weight, $290 \mathrm{~cm}$ of such snow would be needed, which is rather impossible for the area where the Upper Sava valley is located. For comparison, in certain parts of Bavaria and in some north Austrian countries, around 10 February 2006, 1,5 m of snow fell. But due to lower density and WASC than in the Upper Sava valley, the snow weight was significantly lower.

Figure 2 shows the rising of the WASC, the reason for this being that there was no run off from the snow cover. From the red and the blue columns wee see the differences in the WASC of snow which fell on 25 and 26 November and from 26 December to 28 December. The bigger the difference is, the drier

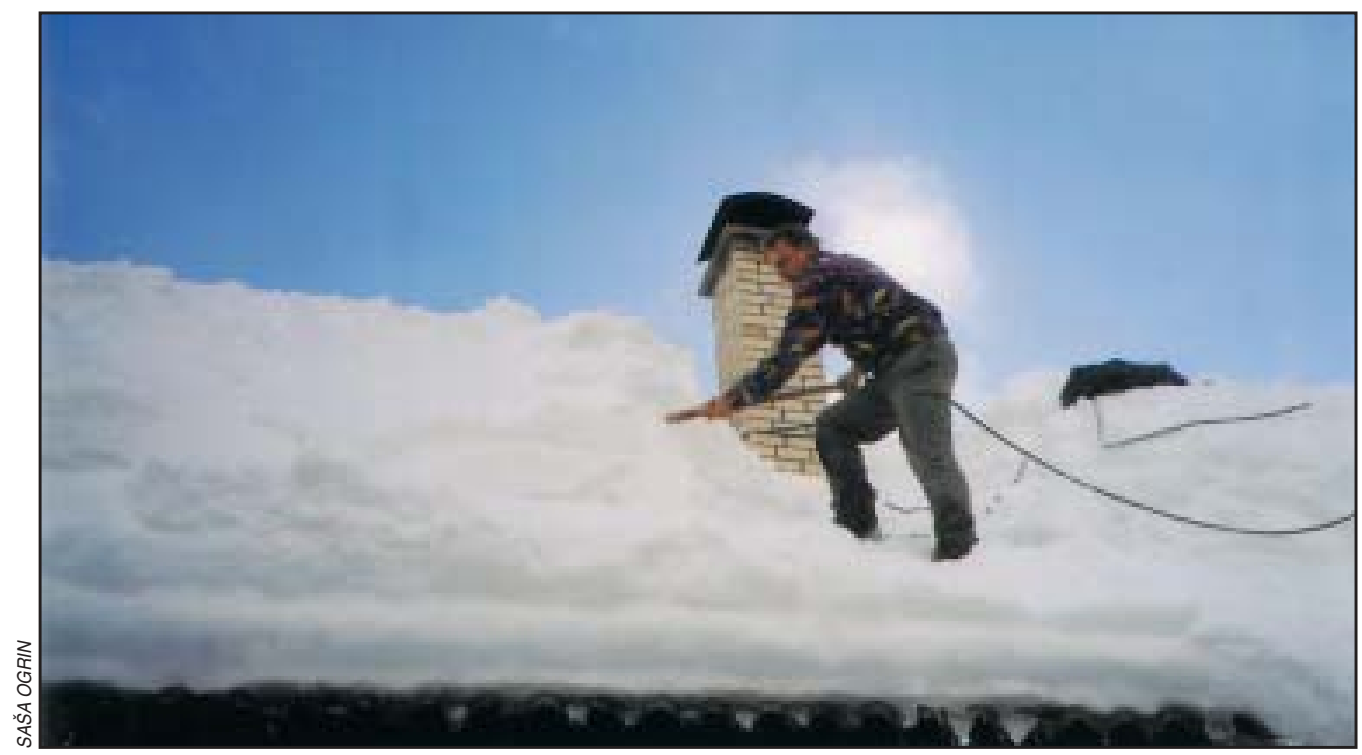

Figure 1: In the Upper Sava valley, some residents threw snow from roofs because of danger that snow would damage the roofs of buildings. 


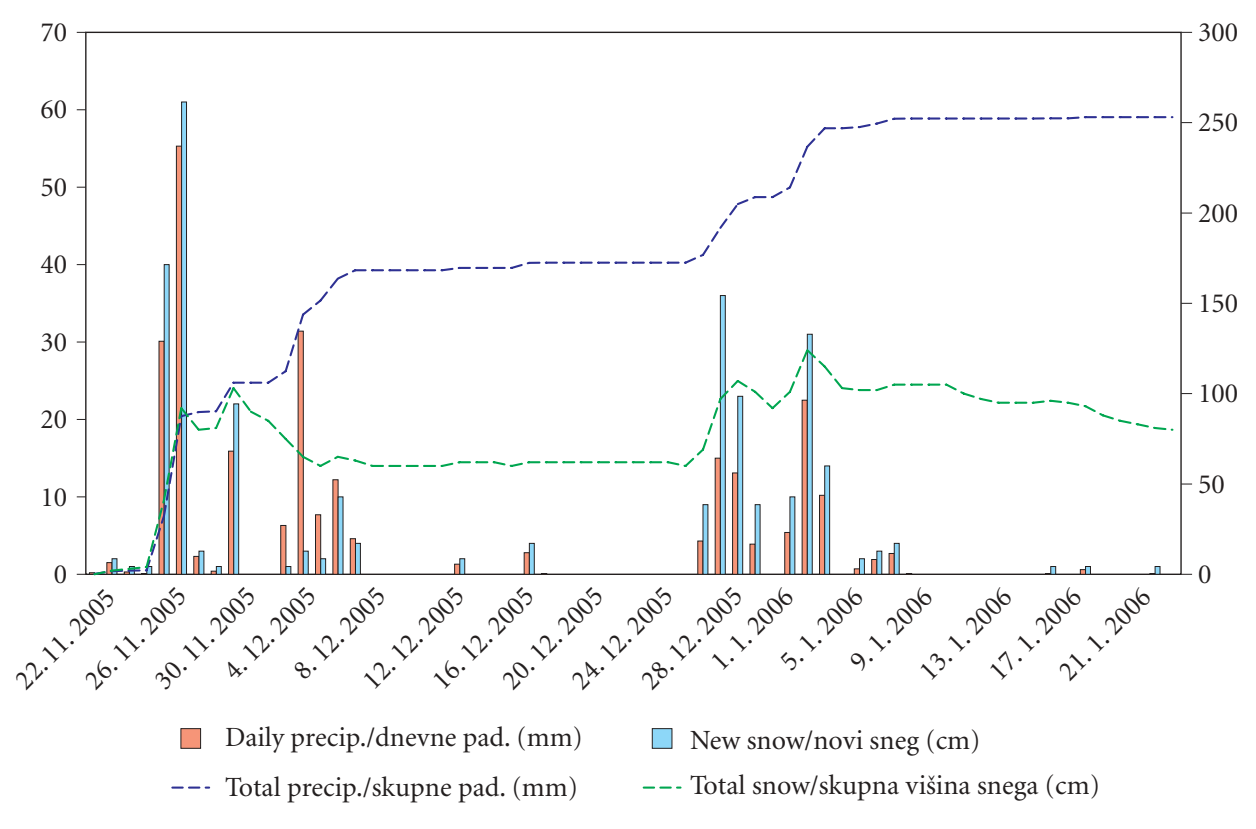

Figure 2: The changing of the snow depth (the right scale in $\mathrm{cm}$ ), the new snow (the left scale in $\mathrm{cm}$ ), the daily precipitation (the left scale in $\mathrm{mm}$ ) and the accumulation of precipitation (the right scale in $\mathrm{mm}$ ) at the meteorological station Rateče from 25 November 2005 to 23 January 2006.

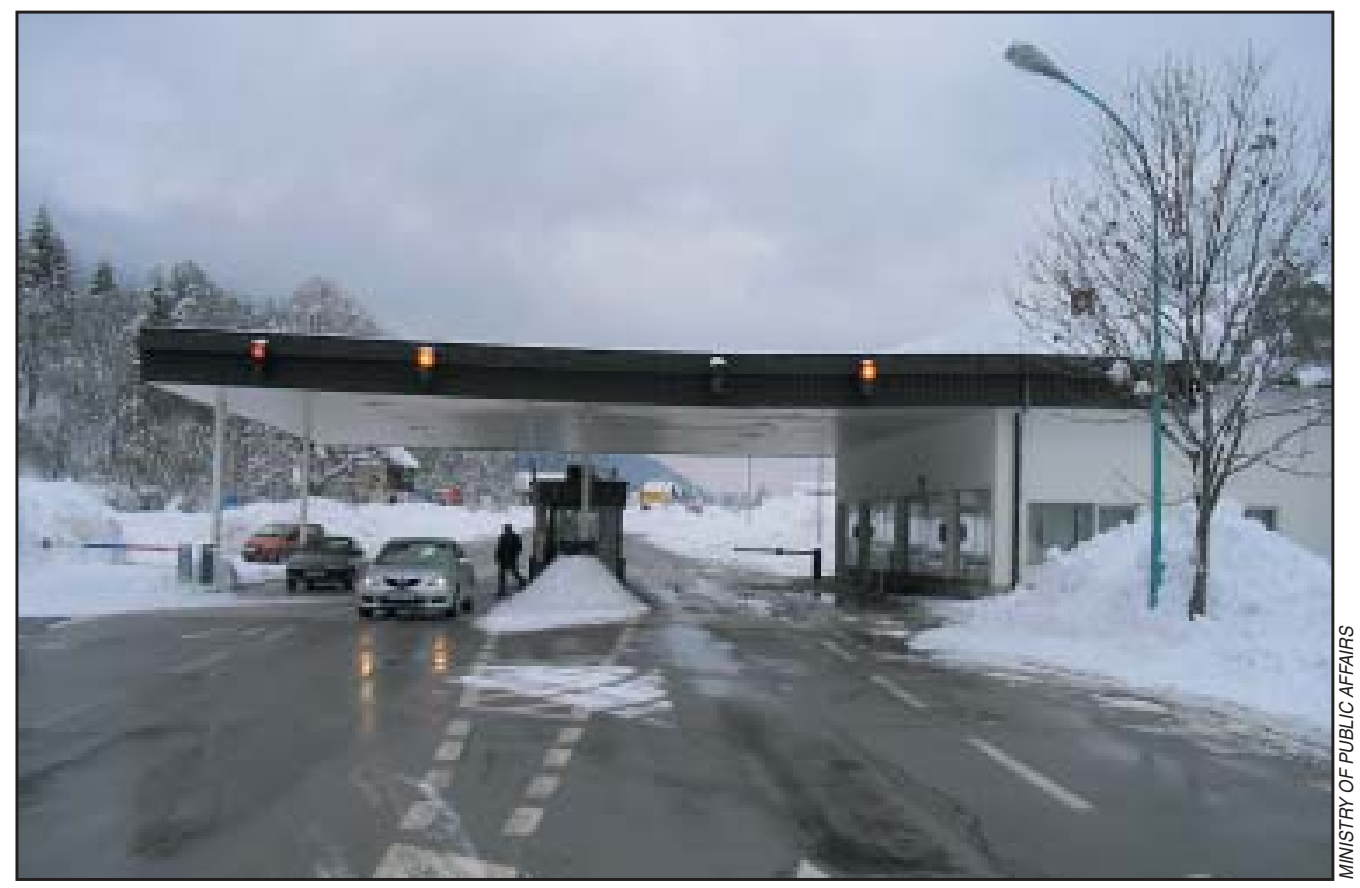

Figure 3: At the boarder crossing Rateče the snow was removed from the roof of the building. 


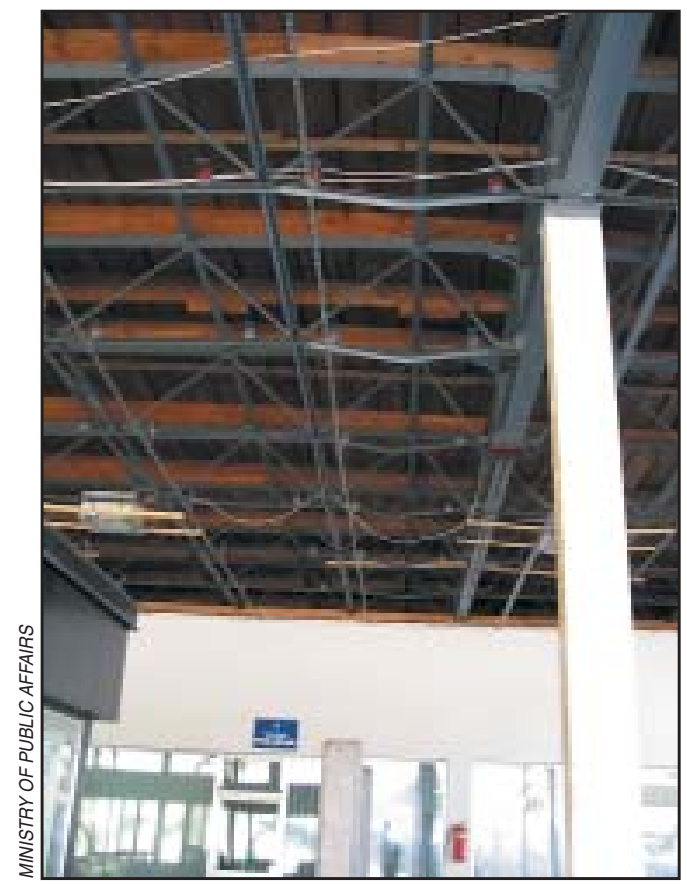

Figure 4: The deformation of the roof construction at the boarder crossing Rateče was so big that traffic underneath was stopped and reconstruction was necessary.

and lighter the snow was. During the first snowfall, relatively warm and very humid Mediterranean air was coming from the southwest (warm advection), except in the lowest part, where, due to inversion, cold air remained trapped in the valley. That is why the snow was heavier than at the end of December, when the snowfall was a result of intensive sinking of cold air from the northeast underneath and the ascending of the relatively warmer humid air above. It can be seen that besides the frequent heavy snowfall, increased snow weight can be also a result of the changing rain and snow precipitation, on condition that deep snow cover is formed. In our case, about $90 \mathrm{~cm}$ of snow at the beginning of winter were enough to sink all of the following rain and melting water. In Slovenia, weather situations when rain and snow change during the winter, are very possible. In addition at warm advection, when rain falls, precipitation is bigger, because warm air contains more moisture than cold air. This causes bigger increase of WASC than during snowfall with cold advection.

Snow weight such as in the Upper Sava valley in the winter 2005/2006, can damage roof construction on some of buildings, which was the case on the building of the boarder police, at the boarder crossing Rateče, between Slovenia and Italy. According to the data of the Ministry for public administration, the roof construction of this building subsided due to snow weight for $45 \mathrm{~cm}$, which exceeded the maximum weight allowed. This deformation caused the closing of the part of the boarder crossing which was underneath that roof for several days. After the snow had been removed from the roof, the construction rose a little towards its initial position. However, the deformation of the construction remained and a reconstruction was necessary.

From the examples described above it can be seen that WASC is an objective indicator of snow cover, because snow depth and its density vary daily, even in dry and cold weather. However, snow depth, which is a good visible indicator, is still most frequently used as an indicator of the amount of snow. This indicator is also the one that people like most. But it does not provide information on density and especially information on the weight of snow, which is very useful information that enables good comparison within time and space.

\section{WASC as an indicator of precipitation in the mountains}

The measuring of precipitation with WASC is a field method and therefore depends on outdoor conditions, such as weather, relief and wind. Wind conditions vary from day to day and from winter to winter. 
When northern to northwestern winds prevail above the Alps then in Slovenia, due to its southeastern position to the main ridge, frequently strong and dry north to northwestern wind called northern foehn blows. It carries the snow from the northern slopes to the southern lee sides. The winds on the interior alpine plateaus are a little bit weaker, but they still cause different accumulation of snow cover in some places. If such weather conditions last long, the depth of snow cover is very irregular and the measurements are very inaccurate. Such was the winter 2004/2005. Snow conditions were very different from place to place. In the very cold period between 5 to 7 February, the measurements were taken in the central part of the Slovenian Julian Alps. On the Fužina plateau, which is relatively well protected from strong winds, the snow depth was quite equal. On the Dedno polje alp (1560) and on the Planina pri Jezeru alp (1453), there were $110 \mathrm{~cm}$ of snow. Conditions were very different in the Triglav lakes valley. In the upper part the depth of snow cover varied from 30 to $220 \mathrm{~cm}$ and in the lower part, near the mountain hut, there were $97 \mathrm{~cm}$ of snow, and it was also more equable. In the upper part of the valley, near the Prehodavci, accurate measurements were not possible.

Winters with frequent strong northern winds are usually dry and sunny, which in addition causes differences in the depth of snow cover between slopes. Snow is icy and hard and most of the windy and sunny slopes can be even without any snow. This worsens conditions for accurate measurements, and usually such measurements are not useful. In winters when weather is generally affected by the north Mediterranean cyclones, snow conditions are much better, and so are the measurements of WASC. The last winters with such conditions in Slovenia were 2003/2004 and 2005/2006.

Table 5: The distribution of snow cover in the central part of the Julian Alps between 5 and 7 February 2005.

\begin{tabular}{lcc}
\hline Location & Elevation $(\mathrm{m})$ & Snow depth $(\mathrm{cm})$ \\
\hline Planina pri Jezeru alp (5.2.2005) & 1453 & 110 \\
Dedno polje alp (5.2.2005) & 1560 & 110 \\
Prehodavci (6.2.2005) & 2020 & $30-220$, very irregular \\
The Triglav lakes (7.2.2005) & 1685 & 97 \\
\hline
\end{tabular}

\subsection{WASC on the Bohinj ridge}

At the end of the winter 2005/2006 WASC was measured at 5 spots of the Bohinj ridge. All measurements were taken with a tube method. The places of the measurements were the Planina Pečana alp on Ratitovec (1480), the Soriška alp (1270), the Ravenska alp (1340), the Zadnji Vogel (1410) and the Planina Govnjač alp (1460). All measurements were taken on 25 and 26 March except on the Zadnji Vogel, where snow was measured on $28 \mathrm{March}$. During this period warm weather prevailed. However, very deep snow prevented any melting water to run off. Evaporation was small and according to our estimation it was negligible.

Ogrin (2005b) made some measurements in the winter 2003/2004. He noticed a gradual decrease of precipitation along the ridge towards the southeast. However, measurements taken in the winter 2005/2006 do not confirm these conditions completely, although they show that the southeastern part of the ridge gets much less precipitation than the western one. It can be seen from Figure 8 that the southeastern part, where the Planina Pečana alp and the Soriška alp are located, gets less precipitation. On the other hand, the Soriška alp gets $46 \mathrm{~mm}$ (4,6\% less) less precipitation than the Planina Pečana alp, which lies eastwards to the Soriška alp. But these differences are relatively small.

Significantly more precipitation fell on the Ravenska alp (31\% more than the Planina Pečana alp) and especially on the Zadnji Vogel alp (58\% more). Further towards the west, on the Planina Govnjač alp, precipitation fell to $85 \%$ of that on the Ravenska alp and $70 \%$ of that on the Zadnji Vogel alp. However, it was still $11 \%$ and $17 \%$ bigger than the precipitation on the Planina Pečana alp and the Soriška alp.

When dealing with precipitation researches along the ridge, it is very important to know how far from the ridge the measuring point is located. Precipitation gradients which are perpendicular to the ridge are much bigger than along it. Namely, also the ascending and descending of air in this direction are faster. 


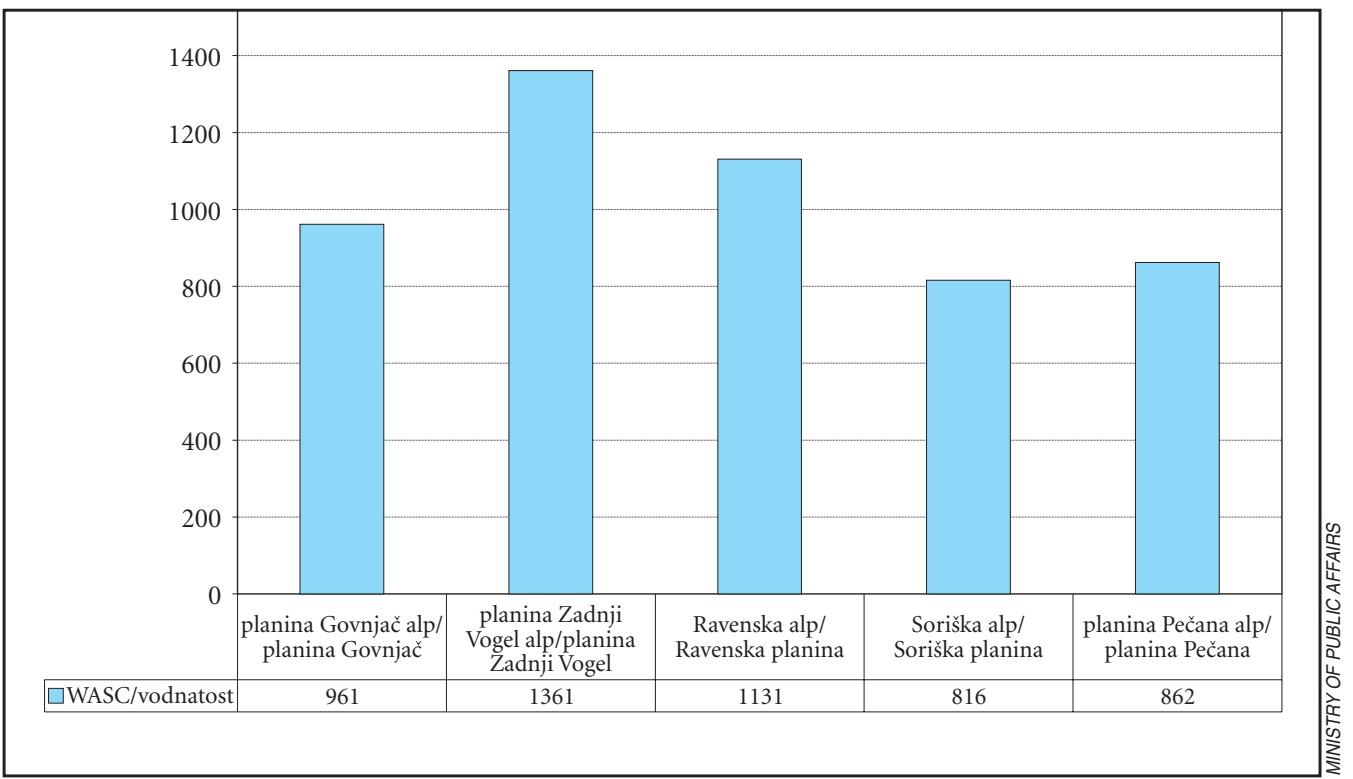

Figure 5: WASC along the Bohinj ridge between 25 and 28 March 2006. It is estimated that the measurement error on the Zadnji Vogel alp is about $10 \%$.

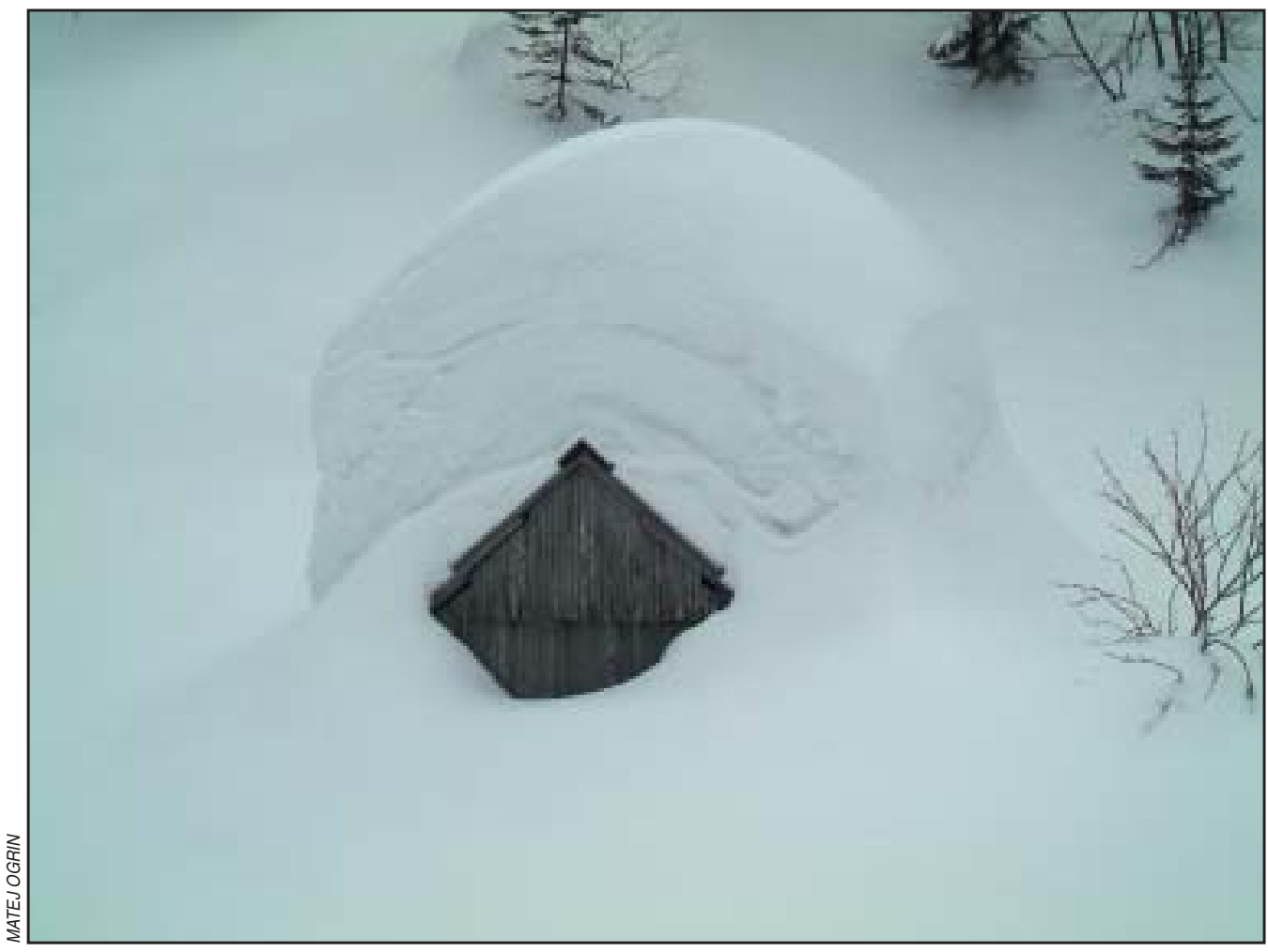

Figure 6: The Ravenska alp on 18 March 2006. Shepherds' huts are almost completely dug in 2,7 m deep snow cover. 
Figure 7: Measurements of snow cover demand a lot of digging into deep snow cover.

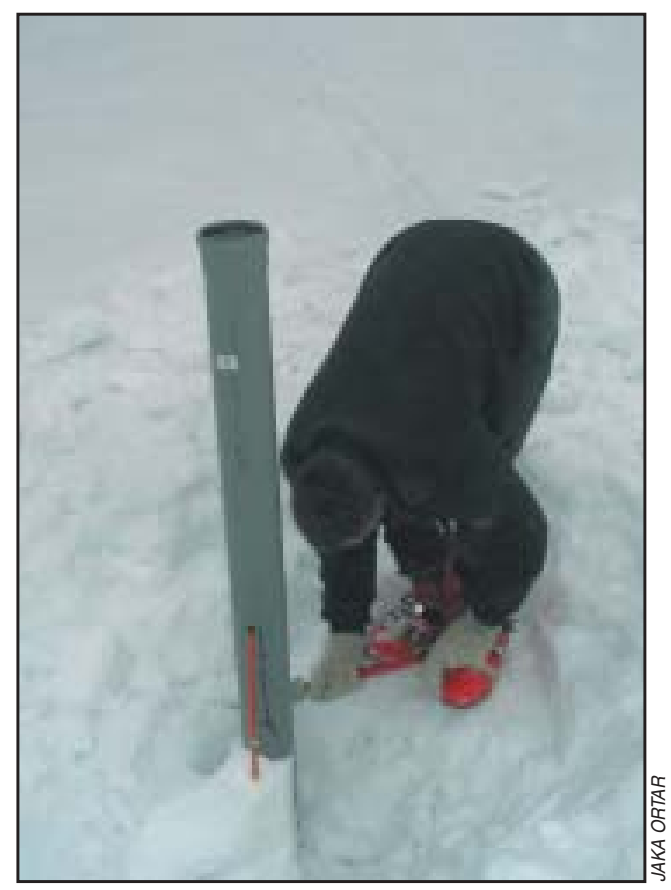

Table 6: The distance of the measuring points from the highest part of the Bohinj ridge.

\begin{tabular}{lccccc}
\hline & Planina. Pečana alp & Soriška alp & Ravenska alp & Zadnji Vogel alp & Planina Govnjač alp \\
\hline Distance from the ridge $(\mathrm{m})$ & $\begin{array}{c}\text { On the plateau. Ridge descends } \\
\text { to the plateau. }\end{array}$ & 1500 & 300 & 1240 & 785 \\
\hline
\end{tabular}

The importance of the distance from the highest part of the ridge can be seen from the comparison of the WASC on the Zadnji Vogel alp and of precipitation measured at the meteorological station on Vogel $(1510 \mathrm{~m})$. The locations are about $1900 \mathrm{~m}$ apart from each other, in the direction southwest-northeast. The station Vogel lies about $2700 \mathrm{~m}$ to the south of the highest part of the ridge, whereas the Zadnji Vogel alp is only $1240 \mathrm{~m}$ away from the highest part of the ridge. From 22 November to $28 \mathrm{March}$, the WASC on the Zadnji Vogel alp was $1361 \mathrm{~mm}$, whereas precipitation measured with a pluviometer on Vogel was $695 \mathrm{~mm}$, which is only $51 \%$ of the precipitation on the Zadnji Vogel alp. It was raining on the day of the measurement on the Zadnji Vogel alp. On Vogel 51,4 mm of precipitation fell. Our estimates are that till the time of the measurement, which happened around noon, about $25 \mathrm{~mm}$ of rain fell.

We have to take into consideration that data from pluviometers in the mountains are systematically underestimated, especially at snowing and in windy conditions. In the last 20 years, Sevruk made a lot of researches on differences between real and measured precipitation in the mountains (Sevruk and Zhalalova 1994; Sevruk and Meiglitz; 2002). He even got the WMO award in 1987 for these efforts. In windy conditions, pluviometers can get only from $22 \%$ to $87 \%$ of all precipitation (Yang et al. 1986). So we see that accurate correction factors are still rather unknown. For the winter 2005/2006 we did not calculate this factor, but we took the factor 1,56 which was calculated for the Vogel in the previous researches (Ogrin 2005b). We only made a correction of the precipitation measured on Vogel. Namely, for other stations in the lowlands these factors are much too high. So, due to this approximation, we can make only a limited comparison.

In the recent years also Vrhovec and Sluga (2000) were dealing with estimates and spatial distribution of precipitation along the Bohinj ridge (2000). The results of their measurements in the winter 1999/2000 showed that most of the precipitation fell on the part of the Bohinj ridge lying to the southwest from the Ski hotel Vogel. According to this study, the maximum occurred on the part of the ridge between the Komna 


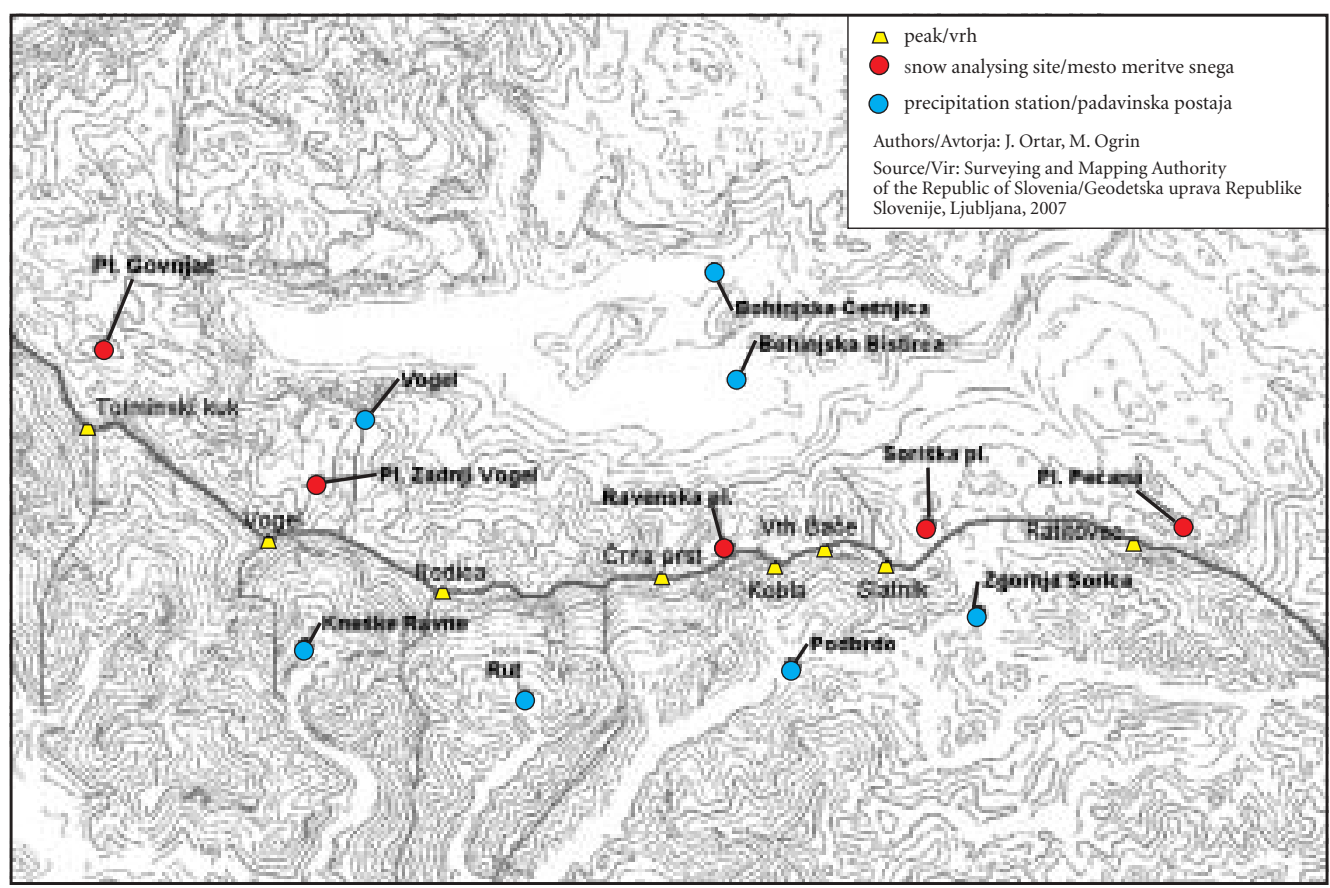

Figure 8: The area of the Bohinj ridge with precipitation stations in its surroundings.

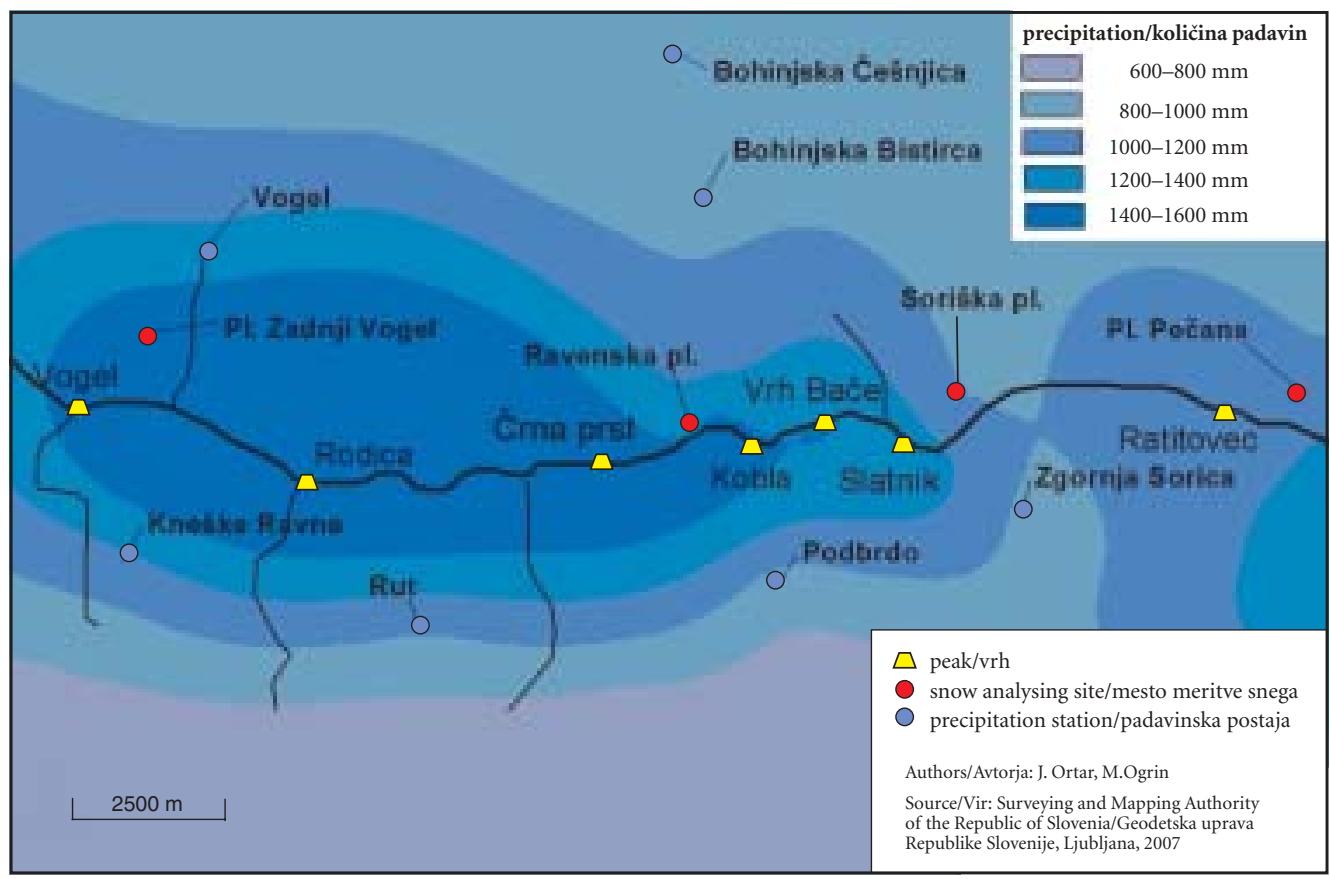

Figure 9: The estimate of the precipitation between 25 November 2005 and 28 March 2006 based on the WASC data and the correction of precipitation at the meteorological station Vogel. 
and Vogel, especially around the mountains the Tolminski Migovec and the Bohinjski Migovec. Our research was based on scarcer data input. Nevertheless, we made an interpolation of the data and a correction of the precipitation data on the ridge (with the correction factor 1,56 at the precipitation station Vogel). This is shown in Figure 9. The results confirmed that precipitation on the ridge in the winter 2005/2006 exceed the precipitation on its edge by up to $40 \%$.

Figure 9 shows the estimates of the precipitation distribution in the winter 2005/2006, with the biggest values somewhere around Rodica $(1966 \mathrm{~m})$. The decrease of precipitation towards the western edge is a result of the lack of data. This is also the reason why the western part of the research area (the Planina Govnjač alp) was cut out in Figure 9. The decrease towards the east is a result of real conditions. The biggest quantities of precipitation on the ridge are estimated at 1400 to $1600 \mathrm{~mm}$. If we presume that the value is $1500 \mathrm{~mm}$, it means that this is about $200 \%$ of the precipitation measured with a pluviometer on Vogel and about $140 \%$ of the corrected precipitation on Vogel (a correction factor 1,56 was taken).

If we wanted to get more accurate data about the precipitation on the ridge, the measurement points should be determined more densely. We would also need more information about the correction factor, which is very important and also unknown. The correction factor that was used for Vogel was calculated on the basis of one winter (2003/2004) and only for the Bohinj side of the ridge. We still do not know the factors for the southern part of the ridge and therefore the data for that part of the ridge are underestimated. On the other hand for the stations on the southern part of the ridge we can not take the same correction factor as for the station Vogel $(1510 \mathrm{~m})$, because their elevation is less than $1000 \mathrm{~m}$ above see level and winds are much weaker. Although there are still many things to find out and discuss, this research confirmed some previous conclusions that precipitation close to the Bohinj ridge is significantly bigger than at locations lying further away from the ridge, such as Vogel. Our estimates show that in the winter $2005 / 2006$ the difference from the ridge to its edge was about $40 \%$.

\section{Conclusion}

Researches showed that snow cover can retain some of its melting water and rain. The deeper the snow cover is the more water it can sink. In the Upper Sava valley, about $1 \mathrm{~m}$ of snow soaked $38 \mathrm{~mm}$ of rain and snow, and the water did not reach the inner layers of snow cover, so there was no run off. The WASC increased and the snow sank to $63 \mathrm{~cm}$. The sinking of snow seemed as melting and it is possible that this brought employees at the boarder crossing Rateče to the conclusion that the snow weight was smaller than it really was.

WASC is a suitable indicator for precipitation in the mountains where the measuring with the method used in the lowlands is impossible. With the tube method we avoid the error which is a result of sampling with a cylinder (problems with edges, thin layers ...). Snowy and less windy winters are appropriate for such researches, because snow cover is much more uniform. On the other hand, dry and windy winters with frequent northern winds and a lot of sunny weather cause a non-uniform distribution of snow, depending on the exposition of slopes. Icy snow is also a problem in such winters.

Precipitation conditions on the Bohinj ridge of the Slovenian Julian Alps are still rather unknown in details. The recent researches showed that precipitation on the ridge differs significantly from precipitation measured at the meteorological station on Vogel, which is located on the very northern edge of the Bohinj ridge, 2,7 km away from its crest. In our study for the winter 2005/2006, the factor of increasing was estimated at about $40 \%$, but the density of our measuring points was scarce.

Although data on snow cover depth are used daily, the information on WASC is much more useful when dealing with properties of snow cover, such as consequences of melting and snow weight on buildings. When rain water which is retained in snow cover freezes, it represents an additional mass which makes the snow cover more resistant to melting.

\section{References}

Arhiv Agencije za okolje Republike Slovenije-ARSO (archives of Slovenian Environmental Agency). 2006. Ljubljana.

Vertačnik, G. 2006: Data from private meteorological station in Vodice near Ljubljana. Internet: http:// freeweb.siol.net/gvertacn/index.html (30.6.2006). 
Ministrstvo za javno upravo (Ministry of Public Affairs). 2006. Ljubljana.

Ogrin, M. 2005a: Private weather diary. Ljubljana.

Ogrin, M. 2005b: Vodnatost snežne odeje kot kazalec količine padavin v gorskem svetu.

Geografski zbornik 45-2. Ljubljana.

Sluga, G. 2000: Prostorska razporeditev akumulacije snežnih padavin vzdolž grebena spodnjih bohinjskih gora v zimi 1997/1998. Razprave 32, Društvo meteorologov Slovenije. Ljubljana.

Sevruk, B., Zahlavova, L. 1994: Classification - System of Preecipitation Gauge Site Exposure - Evaluation and application. International journal of climatology 14-6. Chichestrer.

Sevruk, B., Mieglitz, K. 2002: The effect of topography, season and weather situation on daily precipitation gradients in 60 Swiss valleys. Water Science and Technolgy 45-2. Oxford.

Šegula, P. 1986: Sneg led plazovi. PZS. Ljubljana.

Vrhovec, T. 2000: Small scale precipitation variability in the Julian Alps assesed by snow cover measurements. International Conference on Alpine Meteorology. Innsbruck.

Yang, D., B. Sevruk, E. Elomaa, V. Golubev, B. Goodison, and T. Günther, 1994: Wind-Induced Error of Snow Measurement: WMO Intercomparison Results. Proc. 23d Int. Tagung für Alpine Meteorologie, Annalen der Meteorologie 30. Offenbach am Main. 


\section{Pomen meritev vodnatosti snežne odeje v slovenskih gorskih pokrajinah}

UDK: 911.2:551.578.4(497.452)

COBISS: 1.01

IZVLEČEK: Snežna odeja je v Sloveniji pogost pojav, ki lahko po nižinah leži tudi več mesecev. Od vrste snega in kasnejšega razvoja vremena je odvisno, kakšne obremenitve na infrastrukturo predstavlja snežna odeja. Vodnatost snežne odeje pove količino vode v snežni odeji, s tem pa tudi težo snežne obtežbe. Debelejša snežna odeja je sposobna vpijati lastno snežnico in deževnico, kar pomeni, da kljub taljenju vodnatost snežne odeje ne pada tako hitro, kot bi sklepali sodeč samo po taljenju.

Vodnatost snega je tudi dober pokazatelj količine padavin, kar je uporabno zlasti v gorskem svetu, kjer padavinskih postaj ni (ali pa so postavljene redko in neenakomerno), padavinski gradienti pa so veliki. V zimi 2005/2006 smo s pomočjo vodnatosti snežne odeje prišli do zaključka, da je bila količina padavin na osrednjem delu Bohinjskega grebena Julijskih Alp okoli 40 \% višja kot na njegovem severnem robu, kjer sicer stoji meteorološka postaja Vogel.

KLJUČNE BESEDE: snežna odeja, vodnatost snežne odeje, snežne obtežbe, Zgornjesavska dolina, Bohinjski greben

Uredništvo je prejelo prispevek 30. junija 2006.

NASLOVA

Matej Ogrin, dr.

Oddelek za geografijo

Filozofska fakulteta, Univerza v Ljubljani

Aškerčeva ulica 2, SI - 1000 Ljubljana, Slovenija

E-pošta: matej.ogrin@siol.net

\section{Jaka Ortar, študent}

Oddelek za geografijo

Filozofska fakulteta, Univerza v Ljubljani

Aškerčeva ulica 2, SI - 1000 Ljubljana, Slovenija

E-pošta: ortosplet@gmail.com

\section{Vsebina}

$1 \quad$ Uvod

2 Metoda merjenja vodnatosti snežne odeje

3 Vodnatost snežne odeje in njena sposobnost vpijanja deževnice in snežnice

3.1 Meritve v Vodicah nad Ljubljano

4 Merjenje vodnatosti kot kazalnik količine padavin $\mathrm{v}$ gorskem svetu

4.1 Vodnatost snežne odeje na Bohinjskem grebenu

6 Literatura $\quad 71$ 


\section{Uvod}

Snežna odeja nastane ob sneženju, ko temperatura tal pade na $0{ }^{\circ} \mathrm{C}$ ali manj. Tedaj se snežinke, ki padejo na tla ne talijo več. Snežinke so najrazličnejših oblik: od raznih oblik dokaj pravilnih kristalčkov do povsem neurejenih sprimkov - snežnih kosmov. Ob močnem sneženju je lahko površina tal tudi nekoliko toplejša, kar pomeni, da se snežinke na tleh sicer talijo, vendar je taljenje počasnejše od padanja novih snežink, kar vodi k debeljenju snežne odeje. Ločimo debelino in višino snežne odeje. Debelina predstavlja sloj snežne odeje, ki se meri v smeri pravokotno na podlago, višina pa se vedno meri navpično, ne glede na lego podlage. Na ravni podlagi med tema pojmoma ni razlike, na poševni podlagi (npr. na pobočju) pa prihaja do razlike, in sicer je višina vedno večja kot debelina, razlika pa raste z naklonom podlage.

Snežno odejo sestavljajo ena ali več plasti, te pa deli snežink in zrak med njimi, saj večina snežink ob svojem pristanku spremeni svojo obliko. Snežinke se prelomijo, njihovi morebitni dendriti pa odpadejo. Nekatere se deformirajo po pristanku pod silo trkov drugih snežink in kasnejšega sesedanja in stiskanja. Snovna sestava »suhe« snežne odeje so torej snežni kristali in njihovi sprimki ter vmesni zračni prostor. Ker se del snežink lahko tudi stali, so lahko že v svežem snegu tudi vodne kapljice. Snežna odeja vsebuje torej tudi zrak, ki se vanjo ujame med nalaganjem snežink. Skupna prostornina snežne odeje torej ni enaka vsoti prostornine padlega ledu v snežinkah, pač pa je enaka vsoti prostornin leda in morebitnih vodnih kapljic ter vmesnega prostora, ki ga zapolnjuje zrak.

Tudi ko sneženje preneha, se prostornina snežne odeje neprestano spreminja zaradi sesedanja, četudi so temperature zraka negativne in se sneg ne tali. Snežna odeja se ves čas svojega obstoja preobraža in seseda. Preobrazba je posledica spreminjanja kristalov in snežnih kosmov v zrna, čemur pravimo zrnjenje snežne odeje. Hitrost tega procesa je odvisna od zunanje temperature. Za zrnjenje so idealne večje temperaturne amplitude in dnevno nihanje okoli ledišča. Zrnjenje povzroči zrnato strukturo snega, ki je v starejšem, predelanem snegu lepo vidna (Šegula 1986). Sneg se pri pozitivnih temperaturah tali. Vendar taljenje ni odvisno le od temperature zraka, pač pa tudi od zračne vlage in sevalnih lastnosti atmosfere. V vlažnem zraku in pri oblačnem nebu se npr. ponoči pri isti temperaturi zraka snežna odeja manj ohladi, kot ob zelo suhem zraku in pri povsem jasnem nebu. Pogosto se zgodi, da ob jasnem vremenu kljub pozitivnim temperaturam zraka predvsem $\mathrm{v}$ senčnih legah sneg čez dan ostaja suh ali zmrznjen in se ne tali. To je zaradi sublimacije snežne odeje. Snežna odeja »izhlapeva« neposredno iz ledu v paro (sublimira), kar ji jemlje latentno toploto, to pa jo ohlaja, zato ostaja zmrznjena. Da sublimira $1 \mathrm{~kg}$ ledu, potrebujemo kar 2,8 MJ toplote, ki jo proces jemlje snežni odeji. Količina vodne pare, ki na ta način »izhlapi« iz snežne odeje pa je zelo majhna in pozimi zanemarljiva.

\section{Metoda merjenja vodnatosti snežne odeje}

Vodnatost snežne odeje pove vodni ekvivalent snežne odeje, oziroma koliko vode je shranjene v snegu. Podatek je uporaben za ugotavljanje snežnih obtežb in drugih lastnosti snežne odeje. Navajamo ga v milimetrih ( $\mathrm{mm}$ ) oz. kilogramih na kvadratni meter (kar je številsko enako), prestavlja pa stolpec vode, ki bi nastal, če bi se vsa snežna odeja stalila in ne bi nič vode odteklo ali izhlapelo. Za uporabnost rezultatov merjenja vodnatosti mora biti vzorčenje snežne odeje izvedeno na reprezentativnem mestu. Površina tal mora biti ravna, dovolj daleč od topografskih ovir kot so stavbe, rastje, reliefne oblike itd., ki vplivajo na višino snežne odeje. Torej vzorčenje tudi ne sme potekati na območjih, kjer je dejavna vetrna akumulacija ali erozija, prav tako ne sme biti na območju pojavljanja snežnih plazov. V neposredni okolici tudi ne sme biti virov toplote, ki bi dodatno talili sneg na merilnem mestu (Vrhovec 2000; Sluga 2000; Ogrin 2005b).

V Sloveniji se vodnatost snežne odeje meri na postajah Bilje pri Novi Gorici, Celje, Kredarica, letališče Maribor, Ljubljana Bežigrad, Murska Sobota, Novo mesto, Rateče in Šmartno pri Slovenj Gradcu. V gorskem svetu se torej vodnatost meri le še na Kredarici, v preteklosti pa se je merila tudi v sredogorju, in sicer na Komni in Voglu (ARSO 2006).

V nižinah je merjenje vodnatosti razmeroma preprosto in točno. Če ga izvedemo pravilno, je lahko celo bolj točen pokazatelj količine padavin kot pa so ombrometri, saj se med sneženjem na robovih ombrometrov nabira sneg. Zaradi zapadlega snega postajajo ti robovi vse debelejši, kar veča napako merjenja 
padavin, ne glede na to, ali sneg z robov pade $\mathrm{v}$ ombrometer ali mimo. Teoretično sodi pol snega $\mathrm{z}$ roba v ombrometer, pol pa izven, a točno ločevanje snega je zelo težko izvedljivo. Ker v nižinah večjega dela Slovenije razen na dinarsko kraških predelih in ponekod v subpanonskih, ravninskih predelih, med sneženjem večinoma ni močnih vetrov, se snežna odeja na tleh kopiči v enakomernih plasteh in ne v zametih. Tudi skupne višine snežne odeje večinoma ne presegajo $50 \mathrm{~cm}$, zato je ugotavljanje vodnatosti izvedljivo že s približno $60 \mathrm{~cm}$ visoko cevjo ali posodo, ki jo, z odprto stranjo obrnjeno navzdol, porinemo navpično $\mathrm{v}$ snežno odejo do tal. Manjše napake nastanejo le pri ločevanju snega od tal, a tudi te lahko zanemarimo, če je podlaga gladka. Tudi ravnih tal je v nižinah veliko.

V gorskem svetu so razmere drugačne. Vetrovi so bistveno močnejši, kar pogosto povzroči neenakomerno debelino snežne odeje. Ravnih območij je manj, kar zmanjša uporabnost podatka o debelini snežne odeje, poleg tega pa je debelina bistveno večja kot v nižinah. To otežuje izvedbo vzorčenja in veča napake pri rezultatih. V preteklosti smo vzorčili vsako plast snežne odeje posebej (Ogrin 2005b) in potem izračunali skupno vodnatost. Iz valjastega vzorca dolžine $10,8 \mathrm{~cm}$ in polmera $2,25 \mathrm{~cm}$ smo izračunali gostoto, ki smo jo potem pripisali celotni plasti. Postopek smo ponovili v vsaki plasti, ki smo jo določili po teksturi in barvnem odtenku. Dobra lastnost te metode je vpogled v lastnosti posameznih plasti snežne odeje, slaba pa naraščanje napak, ki se seštevajo pri vzorčenju vsake plasti. V zimi 2005/2006 smo se odločili za metodo enotnega vzorčenja, ki smo ga opravili z 1,5 m dolgo cevjo, ki smo jo porinili navpično v sneg. Ker je bila snežna odeja pogosto debelejša od $1,5 \mathrm{~m}$, smo na takih mestih vzorčili tako, da smo vzorčili po profilu snežne odeje tolikokrat, dokler nismo prišli do podlage. Tako smo tudi precej zmanjšali napake, saj je v prostornini cevi zajet ves sneg prereza od površine do tal. Tudi čas vzorčenja se močno zmanjša. Vmesnih plasti pa na ta način ni moč vzorčiti. Vzorcev nismo tehtali na terenu, pač pa smo jih spravili v vodotesne plastične vreče. Sneg smo nato stalili in stehtali vodo. Lahko bi enostavno stehtali vzorec snega na terenu, a na terenu nismo imeli na voljo dovolj natančne tehtnice, $s$ katero bi lahko stehtali tako velike količine snega. Količino vode, ki ostane na vrečah in posodah smo izmerili s tehtanjem suhih in mokrih vreč ter posod.

Primerjali smo obe metodi, s katerimi smo poskusili določiti razlike, ki se pojavljajo pri merjenju vodnatosti s pomočjo vzorčenja vsake plasti. V primerjavi, ki smo jo opravili januarja $2005 \mathrm{v}$ dolini Planice, smo v enotnem profilu dobili vodnatost $160 \mathrm{~mm}$. Vodnatost s pomočjo vzorčenja posameznih plasti smo izvajali s tremi valji naslednjih dimenzij:

valj $1: \mathrm{r}_{1}=3,95 \mathrm{~cm}, \mathrm{~h}_{1}=9.9 \mathrm{~cm}$, kovinski;

valj $2: \mathrm{r}_{2}=2,25 \mathrm{~cm}, \mathrm{~h}_{2}=10,8 \mathrm{~cm}$, plastični;

valj $3: \mathrm{r}_{3}=3,5 \mathrm{~cm}, \mathrm{~h}_{3}=10,1 \mathrm{~cm}$, plastični.

Zaradi težav pri vzorčenju $\mathrm{z}$ valjem 3 , smo ga iz primerjave izločili. $\mathrm{V}$ tanjših plasteh je bilo namreč vzorčenje z njim nemogoče.

Preglednica 1: Primerjava metode enotnega vzorčenja z metodo vzorčenja vsake plasti posebej. Predpostavimo, da je napaka pri enotnem vzorčenju s cevjo manjša, morda tudi zanemarljiva.

\begin{tabular}{lccc}
\hline & vodnatost v mm & razlika (mm) & razlika (\%) \\
\hline dolina Planice, 29. januar 2005 & & & \\
cev & 160 & 24 & 15,0 \\
valj 1 & 184 & 25 & 15,6 \\
valj 2 & 185 & & \\
\hline Pod Špikom, 3. februar 2005 & 311 & 12 & 4,2 \\
cev & 323 & 2 & 0,6 \\
valj 1 & 313 & & \\
valj 2 & &
\end{tabular}

Preglednica 1 pokaže, da so izmerjene vodnatosti snežne odeje z metodo vzorčenja vsake plasti posebej vedno večje glede na metodo vzorčenja s cevjo. Vidimo, da razlike variirajo od 0,6 do 15,6\%. Odvisno od mesta in termina merjenja. Razlike lahko pojasnimo tudi z različnimi plastmi. V dolini Planice je bila snežna odeja debela $65 \mathrm{~cm}$ v 5 plasteh, pod Špikom pa $110 \mathrm{~cm}$ v 7 plasteh. V tanjši snežni odeji, s tanjšimi plastmi je možnost razlik večja. K razliki pri tovrstnem vzorčenju prispeva tudi zgradba snega. Trše ali nesprijete sipke plasti prinesejo večje razlike, kot mehkejše ali sprijete plasti. 


\section{Vodnatost snežne odeje in njena sposobnost vpijanja deževnice in snežnice}

Snežna odeja se tali na svoji površini, včasih tudi na stiku s podlago. Velika večina staljenega snega na površini kot snežnica pronica skozi snežno odejo proti tlom. Le zelo majhen delež snežnice izhlapi. Ne glede na debelino snežne odeje, se del snežnice zadrži v snežni odeji in zapolni prostor med kristali. Če je snežna odeja dovolj debela in če so v njej plasti z negativno temperaturo, vsa snežnica s površine v notranjih plasteh zmrzne in se zadrži v snegu. Snežna odeja se sicer stanjša, poveča pa se njena gostota, vsebina vode oziroma vodnatost snežne odeje pa ostaja enaka. Podobno se dogaja kadar dežuje. Tedaj vstopajoča voda predstavlja mešanico deževnice in snežnice, kar pomeni, da se, če odtoka ni, masa snežne odeje povečuje. Kako debela mora biti snežna odeja, da zadrži v sebi pronicajočo vodo, je odvisno od količine vode, temperature in zgradbe snega. Svež, gost in nezrnat sneg lahko zadrži več vode kot zrnat sneg. Če imajo notranje plasti negativno temperaturo, voda s površine v notranjosti zmrzuje. Pri tem se sprošča talilna toplota, ki plastem dviga temperaturo največ do $0^{\circ} \mathrm{C}$. Ko so vse plasti v snežni odeji ogrete do te temperature, voda v snegu ne zmrzuje več, pač pa se samo nabira dokler ni sneg z vodo povsem nasičen in je ne more več sprejemati.

Sposobnost snežne odeje, da zadržuje snežnico ali deževnico je pomemben dejavnik, ki vpliva na trajanje snežne odeje in druge lastnosti. Taljenje snega namreč pomeni taljenje snežnih kristalov oziroma taljenje ledu v teh kristalih, pri čemer ogrevanje ali ohlajanje v snegu ujetega zraka zanemarimo, ker v energetskem smislu ni pomembno. Če je voda, ki jo sneg zadrži v notranjih plasteh, po izvoru snežnica, potem ostane vodnatost snežne odeje enaka. Če pa je voda deževnica, pa se vodnatost snežne odeje poveča, saj je pred dežjem v njej ni bilo. Ko kasneje z vodo obogatena snežna odeja pod vplivom zunanje ohladitve zmrzne do tal, postane precej bolj odporna proti taljenju. Razlog je v večji masi in gostoti zmrznjenih kristalov, kar pomeni, da je potrebno dovesti več talilne toplote na enoto prostornine, da se stali. Prav tako pa je sposobnost snežne odeje, da vpija določeno količino vode pomembna pri snežnih obtežbah in nastajanju snežnih plazov.

\subsection{Meritve v Vodicah nad Ljubljano}

V nadaljevanju navajamo primer, ki nazorno kaže, koliko vode je ob odjugi vpila snežna odeja in kaj se je z njo dogajalo. Vsi podatki so bili dobljeni pri preučevanju vodnatosti snežne odeje na amaterski meteorološki postaji dipl. meteorologa G. Vertačnika v Vodicah nad Ljubljano, na nadmorski višini $345 \mathrm{~m}$. Tam je 26. novembra ob 14:15 po močnem sneženju, ki se je začelo 25 . novembra popoldne in je trajalo približno 21 ur, znašala debelina snežne odeje $40 \mathrm{~cm}$. Moker sneg je imel vodnatost $48 \mathrm{~mm}$. Kmalu potem je sneg prešel v dež in popoldne ter v noči na 27 . november je deževalo pri temperaturi med 0 in $2^{\circ} \mathrm{C}$. Do 27. novembra ob 7:00 uri je padlo dodatnih $36 \mathrm{~mm}$ padavin, od tega približno $32 \mathrm{~mm}$ kot dež (zaradi postopnega prehoda sneženja v dež je natančno številko zelo težko določiti, saj je nekaj časa padal tudi dež s snegom oziroma sneg z dežjem). Do 27. novembra ob 7. uri zjutraj se je debelina snežne odeje zmanjšala na $24 \mathrm{~cm}$, oziroma na $60 \%$ debeline prejšnjega dne. Ker so bile temperature ves čas pozitivne, se je sneg talil, talil pa ga je tudi padajoči dež. Vseeno je vodnatost snežne odeje ob tem terminu znašala $53 \mathrm{~mm}$. Torej se je vodnatost povečala za $5 \mathrm{~mm}, 31 \mathrm{~mm}$ padavin pa je odteklo. Snežna odeja se je sesedla iz $40 \mathrm{na} 24 \mathrm{~cm}$. V $24 \mathrm{~cm}$ mokrega snega 27. novembra zjutraj pa je bilo shranjene več vode kot v $40 \mathrm{~cm}$ snega prejšnjega dne. Gostota snega se je povečala iz $120 \mathrm{na} 220 \mathrm{~kg} / \mathrm{m}^{3}$. To pomeni, da je vodnatost snežne odeje narasla kljub temu, da je od 26. novembra popoldne večinoma deževalo, da so bile temperature pozitivne in da je padlo več kot $30 \mathrm{~mm}$ v obliki dežja. Torej so bile snežne obtežbe potem, ko je snežno odejo več kot 12 ur talil in močil dež, zaradi vpijanja deževnice in snežnice večje kot pred dežjem.

Preglednica 2: Spremembe v lastnostih snežne odeje pred in po dežju 26. in 27. novembra 2005 (Vertačnik 2006).

\begin{tabular}{lcccc}
\hline čas meritve & $\begin{array}{c}\text { višina snega } \\
\text { v cm }\end{array}$ & $\begin{array}{c}\text { vodnatost snega } \\
\text { v mm }\end{array}$ & $\begin{array}{c}\text { gostota snega } \\
\text { v kg/m³ }\end{array}$ & opombe \\
\hline $26.11 .2005,14: 15$ & 40 & 48 & 120 & Med meritvami je padlo 36 mm, \\
$27.11 .2005,7: 00$ & 24 & 53 & 221 & od tega 4 mm kot sneg, ostalo kot dež. \\
\hline
\end{tabular}


Drugi primer navajamo iz istega merilnega mesta približno mesec kasneje. V dneh od 26. do 29. decembra 2005 je v občasnem sneženju padlo $44 \mathrm{~cm}$ suhega snega, ki je vseboval $35 \mathrm{~mm}$ vode. Gostota je torej znašala $79 \mathrm{~kg} / \mathrm{m}^{3}$, snežna obtežba pa $35 \mathrm{~kg} / \mathrm{m}^{2}$. V dneh do 6 . januarja 2006 je nato padlo še $29 \mathrm{~mm}$ padavin v obliki dežja in $16 \mathrm{~mm} v$ obliki snega. 8. januarja 2006 zvečer je vodnatost znašala $57 \mathrm{~mm} \pm 3 \mathrm{~mm}$, debelina snežne odeje pa $23 \mathrm{~cm}$. Vidimo, da je gostota narasla na $248 \mathrm{~kg} / \mathrm{m}^{3}$, snežna obtežba pa je znašala $57 \mathrm{~kg} / \mathrm{m}^{2}$. Gostota se je torej več kot potrojila. Če predpostavimo, da se sneg v teh dneh ni talil tako hitro, da bi iz njega odtekla bistvena količina snežnice, saj so bile temperature od 1 . januarja do 8 . januarja ves čas v intervalu med -3 in $2,6^{\circ} \mathrm{C}$ (Podatki z meteorološke ... 2006), potem moramo k seštevku padavin v obliki snega $(35 \mathrm{~mm}+16 \mathrm{~mm})$ dodati vsaj še približno $6 \mathrm{~mm}$ iz dežja. Torej je dež kljub taljenju snežne odeje povzročil vodni in s tem masni pribitek snežni odeji. Če pa je predpostavka o zanemarljivem odtoku vode iz snežne odeje napačna, pa je zadržek deževnice še toliko večji, kolikor vode je iz snega odteklo zaradi taljenja.

Preglednica 3: Spremembe v lastnostih snežne odeje v Vodicah nad Ljubljano med 29. decembrom 2005 in 8. januarjem 2006 (Vertačnik 2006).

\begin{tabular}{lcccc}
\hline čas meritve & $\begin{array}{c}\text { višina snega } \\
\text { v cm }\end{array}$ & $\begin{array}{c}\text { vodnatost snega } \\
\text { v mm }\end{array}$ & $\begin{array}{c}\text { gostota snega } \\
\text { v kg/m³ }\end{array}$ & opombe \\
\hline 29.12.2005, 21:00 & 44 & 35 & 79 & \\
8.1.2006, zvečer & 23 & 57 & 248 & Vmes je padlo 45 mm padavin, \\
& & & & od tega 16 mm v obliki snega. \\
\hline
\end{tabular}

\subsection{Snežne obtežbe v Zgornjesavski dolini}

Navedena primera lepo kažeta sposobnost snežne odeje, da zadrži oziroma vpije vodo, ki pronica skoznjo. Glede na majhne količine snega, je bilo zadrževanje temu primerno majhno in brez opaznejših posledic. Drugače pa je bilo v tej zimi v Zgornjesavski dolini (v nadaljevanju Dolini). Zima s strnjeno snežno odejo se je v Ratečah začela 23. novembra 2005. Tedaj je bila snežna odeja še zelo skromna in je znašala le $2 \mathrm{~cm}$. 24. novembra se je odebelila za dodaten centimeter, nato pa je 25. novembra 2005 začelo snežiti, sneženje pa je ponehalo šele 27. novembra 2005 zjutraj in je trajalo neprekinjeno približno 40 ur. Skupna debelina snežne odeje je na ta dan znašala v Ratečah 92 cm, v Gozdu Martuljku pa $89 \mathrm{~cm}$ (ARSO 2006; Ogrin 2005a).

Snežna odeja se je nato ponovno odebelila čez 2 dni, ko je 29. novembra snežilo in do 30 . novembra zjutraj zapadlo $22 \mathrm{~cm}$ novega snega, skupna debelina pa je znašala $103 \mathrm{~cm}$. Meter debela snežna odeja je vsebovala $106 \mathrm{~mm}$ padavin (ARSO 2006). Gostota snega je znašala $103 \mathrm{~kg} / \mathrm{m}^{3}$, snežna obtežba pa $106 \mathrm{~kg} / \mathrm{m}^{2}$. Nato je novo večje padavinsko obdobje zajelo Slovenijo 2. decembra zvečer, padavine pa so trajale še 3. decembra in v noči na 4. december ponehale. Le na začetku je ponekod pod $1000 \mathrm{~m}$ še rahlo snežilo, najkasneje v noči na 3. decembra pa se je meja sneženja dvignila na okoli $1300 \mathrm{~m}$, razen v Dolini, kjer je bila meja sneženja med 900 in $1100 \mathrm{~m}$. V Ratečah je v tem obdobju padlo $38 \mathrm{~mm}$ padavin, od tega $4 \mathrm{~cm}$ kot sneg ( $1 \mathrm{~cm}$ na začetku in 3 na koncu padavin). Vmes je večinoma padal dež s snegom, zjutraj sprva samo dež, sredi dneva in popoldne pa večinoma sneg. Temperatura je bila med 0 in $2{ }^{\circ} \mathrm{C}$. Nižje po Dolini je bilo več dežja kot snega, le sprva je v noči na 3 . decembra padlo okoli $2 \mathrm{~cm}$ snega. Nato so se do 7. decembra občasno še pojavljale padavine, skupaj je $\mathrm{v}$ Ratečah padlo še $24,5 \mathrm{~mm}$ padavin, večinoma kot sneg, le sprva tudi kot dež. Padlo je $16 \mathrm{~cm}$ snega, snežna odeja pa je bila 7. decembra zvečer debela $63 \mathrm{~cm}$. Do 26. decembra je nato prevladovalo večinoma suho vreme, temperature pa so bile dovolj nizke, da se sneg ni bistveno talil, saj je bil december 2005 v Dolini opazno hladnejši od povprečja. Srednja mesečna temperatura v Ratečah je znašala $-5,7^{\circ} \mathrm{C}$, najvišja izmerjena temperatura $3,6^{\circ} \mathrm{C}$, najnižja pa $-17,9^{\circ} \mathrm{C}$. 26 . decembra je bila višina snežne odeje $60 \mathrm{~cm}$. Nato je v dneh od 26. decembra 2005 do 8 . januarja 2006 ponovno pogosto snežilo. Skupaj je zapadlo $141 \mathrm{~cm}$ snega, zaradi sesedanja pa je skupna višina snežne odeje ob koncu padavin 7. januarja 2006 znašala $105 \mathrm{~cm}$. 2. januarja je znašala celo $124 \mathrm{~cm}$. 7. januarja 2006 se je pričelo daljše suho in hladno obdobje, ki se je končalo v sredini februarja. Vmes je le prehodno nekajkrat rahlo naletaval sneg (ARSO 2006).

22. januarja 2006 smo v Gozdu Martuljku opravili test vodnatosti snežne odeje in ugotovili, da je $80 \mathrm{~cm}$ debela snežna odeja vsebovala $233 \mathrm{~mm}$ padavin. To pomeni gostoto $291 \mathrm{~kg} / \mathrm{m}^{3}$ oziroma obtežbo $233 \mathrm{~kg} / \mathrm{m}^{2}$. 
Med Ratečami $(865 \mathrm{~m})$ in Gozdom Martuljkom $(750 \mathrm{~m})$ je razdalja $10 \mathrm{~km}$, kar pomeni, da lahko prihaja do manjših razlik v količini padavin.

Preglednica 4: Lastnosti snežne odeje v Gozdu Martuljku 22. januarja 2006.

\begin{tabular}{lcccc}
\hline čas meritve & $\begin{array}{c}\text { višina snega } \\
\mathrm{v} \mathrm{cm}\end{array}$ & $\begin{array}{c}\text { vodnatost snega } \\
\mathrm{v} \mathrm{mm}\end{array}$ & $\begin{array}{c}\text { snežna obtežba } \\
\mathrm{v} \mathrm{kg} / \mathrm{m}^{2}\end{array}$ & $\begin{array}{c}\text { gostota snega } \\
\mathrm{v} \mathrm{kg} / \mathrm{m}^{3}\end{array}$ \\
\hline 22.1 .2006 & 80 & 233 & 233 & 291 \\
\hline
\end{tabular}

Vsota padavin, ki so od 23. novembra padle v Ratečah, je bila $253 \mathrm{~mm}$. Razlika med vodnatostjo, izmerjeno v Gozdu Martuljku je $20 \mathrm{~mm} v$ prid Ratečam in je zelo verjetno posledica različne intenzitete padavin, ne pa odtekanja vode iz snežne odeje, saj se v času edinega dežja v Dolini, (3. in 4. december) globlje plasti tedaj približno $70 \mathrm{~cm}$ debele odeje niso niti ojužile. Na stari snežni odeji je ob dežno snežnih padavinah nastala približno $2 \mathrm{~cm}$ debela plast plundre, ki je bila mešanica padajočega dežja in snega in je vsebovala velik del novih padavin. Višina snežne odeje se je v tem času ves čas spreminjala, vodnatost pa je naraščala. Obtežba $233 \mathrm{~kg} / \mathrm{m}^{2}$ predstavlja veliko breme stavbam, zato so marsikje v Dolini v bojazni pred poškodbami ostrešij začeli z odmetavanjem snega s streh. Kljub ne zelo veliki debelini snežne odeje, ki v tem obdobju ni presegla $124 \mathrm{~cm}$, je bila obtežba precejšnja, saj se je snežna odeja zaradi dežja močno sesedla hkrati pa se ji je povečala vodnatost, kajti odtekanja iz snežne odeje zaradi njene debeline ni bilo.

Sneg, ki pade med sneženem ob negativnih temperaturah, ima povprečno gostoto pod $100 \mathrm{~kg} / \mathrm{m}^{3}, \mathrm{kar}$ pomeni, da bi za enake obtežbe moralo pasti dva do tri metre snega s tako gostoto, kar je v naših krajih precej neverjeten dogodek. Tudi obline snežne padavine na Bavarskem, v avstrijskih deželah Zgornja Avstrija, Spodnja Avstrija in v delu Štajerske v dneh okoli 10. februarja 2006, ko je bila marsikje ob koncu padavin snežna odeja visoka $1,5 \mathrm{~m}$, so v resnici povzročile precej manjše snežne obtežbe, kot smo jim bili priča v Dolini v zimi 2005/2006, saj je bil sneg manj gost in zato lažji.

Slika 1: V Dolini so nekateri v januarju 2006 sneg metali s streh zaradi bojazni pred poškodbami ostrešij zaradi prevelike snežne obtežbe. Glej angleški del prispevka.

Slika 2: Spreminjanje višine snežne odeje in dnevne količine novozapadlega snega (skala na levi, $v \mathrm{~cm}$ ), ter prirastek padavin in dnevna količina padavin (skala na desni, v mm) za postajo Rateče od 22. novembra 2005 do 23. januarja 2006.

Glej angleški del prispevka.

Slika 2 nazorno pokaže, kako se je količina padavin (ker odtoka iz snežne odeje ni bilo, ji lahko rečemo tudi vodnatost snežne odeje) postopno večala, medtem ko je višina snežne odeje zaradi sesedanja in novega snega precej nihala. V poslabšanjih 25. in 26. novembra 2005 ter pred novim letom se lepo vidi razlika $\mathrm{v}$ vodnatosti snega ob poslabšanjih. V prvem primeru je prevladovala topla južna do jugozahodna advekcija, ki prinaša veliko vlage in povzroča gost sneg, medtem ko je v drugem primeru, okoli novega leta snežilo pri nizkih temperaturah ob klasičnem vremenskem stanju mrzlih vetrov iz severnega kvadranta $\mathrm{v}$ nižjih plasteh ter nekoliko toplejših jugozahodnih vetrov $\mathrm{v}$ višinah. $\mathrm{V}$ tem primeru so gostote snega precej nižje kot v prvem, kar kaže velikost razkoraka modrih in rdečih stolpcev na Sliki 2.

Poleg pogostih in obilnih snežnih padavin povzroča velike snežne obtežbe tudi menjavanje snežnih in dežnih padavin, če pada dež na debelo snežno odejo, ki deževnico in snežnico vpije. Potencialno so taka vremenska stanja še bolj nevarna, saj so v naših krajih pogostejša. Znano pa je dejstvo, da količine padavin v toplem zraku presegajo tiste v hladnem. Če ta voda ostane v snegu, to presega obtežbe povzročene samo s sneženjem.

Snežne obtežbe, kakršne so bile v zimi 2005/2006 v Dolini, lahko že predstavljajo preobremenitve, ki povzročijo poškodbe na posameznih stavbah, kar potrjujejo dogodki na mejnem prehodu Rateče. Po podatkih Ministrstva za javno upravo, je prišlo tam do nagiba ostrešja mejnega prehoda za $45 \mathrm{~cm}$, kar je povzročilo deformacijo strešne konstrukcije do te mere, da so morali cestišče pod streho in s tem del mejnega prehoda začasno zapreti. Ko so odmetali sneg z ostrešja, se je ostrešje nekoliko dvignilo proti prvotni legi, a so deformacije v konstrukciji ostale. Konstrukcijo so podprli in usposobili za opravljanje svoje funkcije.

Vodnatost snežne odeje torej predstavlja količino vode v snegu in je objektiven kazalec snežne odeje, saj se debelina in gostota spreminjata dnevno tudi v suhem vremenu in pri negativnih temperaturah. 
Najpogosteje se pri opisu snežnih razmer uporablja višino snežne odeje, ki je dober kazalec za vizualen opis razmer. Je tudi kazalec, ki ga ljudje najpogosteje uporabljamo in najbolj razumemo. Vendar samo s poznavanjem višine ne dobimo informacije o gostoti, snežnih obremenitvah in vsebnosti vode v snegu, to pa so vsebinsko precej bolj uporabni podatki, ki omogočajo tudi večjo primerljivost med seboj.

Slika 3: Mejni prehod Rateče potem, ko so s strehe odstranili težko snežno odejo.

Glej angleški del prispevka.

Slika 4: Poškodbe na mejnem prehodu Rateče so bile tolikšne, da je bila potrebna sanacija objekta, promet pod streho pa začasno prepovedan. Glej angleški del prispevka.

\section{Merjenje vodnatosti kot kazalnik količine padavin v gorskem svetu}

Ugotavljanje količine padavin na nekem območju z metodo vodnatosti snežne odeje je terenska metoda in tako odvisna od zunanjih razmer, predvsem vremenskih in reliefnih. Na kakovost rezultatov poleg že omenjenih dejavnikov (lokacija, temperatura in padavine) najbolj vplivajo vetrovne razmere. Te se od zime do zime lahko precej razlikujejo. Kadar nad Alpami prevladuje severni do severozahodni višinski tok, tedaj $\mathrm{v}$ slovenskem gorskem svetu, ki leži jugovzhodno od glavnega grebena, pogosto piha močan in sunkovit fenski severni do severozahodni veter (severni fen), ki prenaša snežno odejo, gradi zamete in opasti na južnih straneh pobočij. Na sredogorskih planotah vetrovi že nekoliko oslabijo, vseeno pa marsikje povzročijo neenakomerno debelino snežne odeje. Če se tako vremensko stanje pojavlja pogosto in traja dolgo, je snežna odeja $v$ gorskem svetu zelo neenakomerna. $V$ takem primeru je merjenje debeline, ki bi bila reprezentativna za večje območje, težko izvedljivo. Primer take zime je bila zima 2004/2005. Tedaj so bile snežne razmere zelo raznolike in je bilo marsikje nemogoče izmeriti reprezentativno vodnatost. V osrednjem delu Julijskih Alp smo v zelo mrzlem obdobju od 5. do 7. februarja 2005 merili višino snežne odeje. Na Fužinarskih planinah, ki so pred močnim severnim vetrom zaščitene z osrednjim masivom Julijskih Alp, je bila višina snežne odeje izenačena, na Planini Dedno polje in na Planini pri Jezeru je znašala debelina snežne odeje $110 \mathrm{~cm}$. Povsem drugačne pa so bile razmere v dolini Triglavskih jezer. V zgornjem delu doline je debelina znašala od 30 do $220 \mathrm{~cm}$, med tem ko je bila v okolici koče $97 \mathrm{~cm}$. Zgornji del doline pod Prehodavci ni bil primeren za ugotavljanje vodnatosti snežne odeje.

Zime, $\mathrm{v}$ katerih je pogost močan severni in severozahodni veter, so $\mathrm{v}$ naših gorah ponavadi tudi zelo suhe in sončne, kar še dodatno otežuje razmere za dobro merjenje, saj je snežna odeja še bolj neizenačena. Daljša sušna obdobja večajo razlike med pobočji, močan veter pa še povečuje razlike v debelini snežne odeje. Poleg prisojnih pobočij so zato skoraj brez snega tudi privetrna območja, tam pa je lahko sneg tudi zelo zbit in trd. Kadar pa so zime s snegom bolj bogate, ko so pogosta sneženja pod vplivom sekundarnih ciklonov v severnem Sredozemlju, tedaj so razmere za merjenje vodnatosti bistveno bolj ugodne. Snežna odeja je veliko bolj enakomerna, kar močno olajša ugotavljanje prave višine in vodnatosti snežne odeje. V bližnji preteklosti sta bili taki zimi 2003/2004 in 2005/2006.

Preglednica 5: Razporeditev snežne odeje v suhi in vetrovni zimi 2004/2005 v osrednjem delu Julijskih Alp med 5. in 7. februarjem 2007.

\begin{tabular}{lcc}
\hline lokacija & nadmorska višina $(\mathrm{m})$ & višina snežne odeje $(\mathrm{cm})$ \\
\hline Planina pri Jezeru (5.2.2005) & 1453 & 110 \\
Planina Dedno polje (5.2.2005) & 1560 & 110 \\
pod Prehodavci (6.2.2005) & 2020 & $30-220$, močno spihano \\
koča pri 7 jezerih (7.2.2005) & 1685 & 97 \\
\hline
\end{tabular}

\subsection{Vodnatost snežne odeje na Bohinjskem grebenu}

Proti koncu zime 2005/2006 smo na 5 mestih v sredogorju na Bohinjskem grebenu izmerili vodnatost snežne odeje z metodo enotnega vzorčenja s cevjo. Vzorčili smo na Planini Pečani ( $1480 \mathrm{~m})$ pod Ratitovcem, na Soriški planini (1270 m), na Ravenski planini (1340 m), na Planini Zadnji Vogel (1410 m) in na 
Planini Govnjač (1460 m). Vzorčenje je potekalo 25. in 26. marca, le na Zadnjem Voglu smo vzeli vzorec 28. marca 2006. Kljub temu, da so v dneh vzorčenja že prevladovale pozitivne temperature tudi v sredogorju, je velika količina snega, ki je zaznamoval zimo 2005/2006 preprečila odtekanje snežnice v tla, izhlapevanje pa je bilo po naši oceni zelo majhno.

Slika 5: Vodnatost snežne odeje vzdolž Bohinjskega grebena med 25. in 28. marcem 2006.

Ocena napake je okoli $10 \%$.

Glej angleški del prispevka.

Ogrin (Ogrin 2005b) navaja postopen padec količine padavin vzdolž grebena proti jugovzhodu, ki se je pokazal v zimi 2003/2004. Razmere v zimi 2005/2006 tega niso potrdile v celoti. Očitna je manjša vodnatost na jugovzhodnem delu grebena (čeprav ima nekoliko zahodneje ležeča Soriška planina $46 \mathrm{~mm}$ manjšo vodnatost kot Planina Pečana, a je razlika zelo majhna, le 4,6 \% in je v primerjavi z razlikami med ostalimi merilnimi mesti najmanjša). Ravenska planina prejme že $31 \%$ več kot Pečana, Zadnji Vogel pa celo $58 \%$ več. Na Zadnjem Voglu je ocenjena napaka meritve na $\pm 10 \%$. Očitno manjšo vodnatost pa smo namerili na Govnjaču. Vodnatost je sicer večja kot na Pečani in Soriški planini, (za 11 \% oz. 17 \%), a po drugi strani doseže le $85 \%$, oziroma 70 \% vodnatosti na Ravenski planini in na Zadnjem Voglu.

Slika 6: Ravenska planina 18. marca 2006. Stan je vkopan v 270 cm debelo snežno odejo.

Glej angleški del prispevka.

Slika 7: Meritve vodnatosti snežne odeje terjajo tudi naporno kopanje v snežno odejo.

Glej angleški del prispevka.

Pri obravnavanju padavinskih razmer vzdolž gorskih grebenov je zelo pomembna tudi oddaljenost merilnega mesta od osrednjega dela grebena. Gradienti intenzitete padavin prečno na greben so vedno precej večji kot vzdolž njega, saj je tudi dviganje in spuščanje zraka v tej smeri hitrejše.

Preglednica 6: Oddaljenost merilnega mesta (m) od osrednje osi Bohinjskega grebena.

\begin{tabular}{lccccc}
\hline & Planina Pečana & Soriška planina & Ravenska planina & Planina Zadnji Vogel & Planina Govnjač \\
\hline oddaljenost od grebena $(\mathrm{m})$ & na planoti & 1500 & 300 & 1240 & 785 \\
\hline
\end{tabular}

Pomembnost oddaljenosti od grebena se do neke mere da razbrati iz primerjave količine padavin na Voglu in vodnatosti na Planini Zadnji Vogel. Točki sta oddaljeni približno $1900 \mathrm{~m}$ v smeri jugozahod severovzhod. Merilno mesto Vogel leži približno 2700 m južneje od grebena, Planina Zadnji Vogel pa približno $1240 \mathrm{~m}$. V obdobju od 22. novembra do 28. marca se je na Zadnjem Voglu v snežni odeji nabralo kar $1361 \mathrm{~mm}$ padavin, medtem ko je ombrometer pri Ski hotelu na Voglu nameril le $695 \mathrm{~mm}$, kar je le 51 \% količine na Zadnjem Voglu. Ker je na dan merjenja vodnatosti snežne odeje na Zadnjem Voglu deževalo in je $\mathrm{v}$ tem dnevu pri meteorološki postaji na Voglu padlo $51,4 \mathrm{~mm}$ padavin, smo ocenili, da se je do sredine dneva, ko je bil vzorec snega pobran, vanj nabralo približno $25 \mathrm{~mm}$ padavin tistega dne.

Če želimo v obravnavo vključiti tudi podatke iz dežemerov, moramo upoštevati, da meritve z njimi sistematično podcenjujejo količino padavin, še posebej ob sneženju tudi ob vetru. $S$ tem problemom se je najbolj izčrpno ukvarjal Sevruk, ki je v zadnjih več kot dvajsetih letih objavil vrsto člankov in ekspertnih študij o razlikah med izmerjenimi in dejanskimi padavinami (in bil za te svoje raziskave od Svetovne meteorološke organizacije leta 1987 tudi nagrajen; npr. Sevruk in Zhlalova 1994; Sevruk in Meiglitz 2002). Ob različno vetrovnem vremenu pa dežemeri ujamejo le 22 do $87 \%$ vseh padavin (Yang in ostali 1986). Tako so tudi korekcijski faktorji med dežemeri in vodnatostjo snežne odeje za naš primer še velika neznanka, kajti v zimi 2005/2006 ga nismo posebej ugotavljali. V tej raziskavi smo zato za korekcijo padavin na postaji Vogel vzeli faktor 1,56, ki ga za postajo Vogel navaja Ogrin (2005b). Na ta način vseeno lahko vsaj približno primerjamo meritve $\mathrm{z}$ dežemeri $\mathrm{z}$ našimi meritvami vodnatosti snežne odeje.

Z oceno in prostorskim prikazom padavin na Bohinjskem grebenu sta se $\mathrm{v}$ zadnjih letih ukvarjala tudi Vrhovec in Sluga, ki sta v zimi 1999/2000 prišla do zaključka, da višek padavin prejme del Bohinjskega grebena jugozahodno od Ski hotela Vogel (Vrhovec 2000; Sluga 2000). V svoji raziskavi navajata, da je 
bil padavinski maksimum zabeležen na delu grebena med Voglom in Komno v okolici Tolminskega in Bohinjskega Migovca. Naša raziskava je imela precej bolj redko mrežo merilnih točk, vseeno pa smo z interpolacijo podatkov in preračunavanjem padavinskih podatkov (s korekcijskim faktorjem 1,56 za postajo Vogel) napravili približno oceno prostorske razporeditve padavin dela grebena, ki je prikazana na sliki 9. $\mathrm{Na}$ ta način je naša raziskava potrdila ugotovitve predhodnih, da so padavinske akumulacije na grebenu bistveno večje od tistih na postaji Vogel. Po naši oceni je v zimi 2005/2006 znašal ta prirast okoli $40 \%$.

Slika 8: Obravnavano območje Bohinjskega grebena s padavinskimi postajami v okolici.

Glej angleški del prispevka.

Slika 9: Ocena padavin od 25. novembra 2005 do 28. marca 2006 na podlagi meritev ARS0 in vodnatosti snežne odeje. Za severni del grebena smo meritve ARSO na Voglu korigirali s faktorjem 1,56.

Glej angleški del prispevka.

Slika 9 pokaže oceno razporeditve padavin v zimi 2005/2006 z vrhom nekje okoli Rodice (1966 m). Tanjšanje pasu padavinskega maksimuma proti zahodnemu robu karte je posledica pomanjkanja podatkov. Zaradi redke mreže meritev smo iz slike 9 izpustili območje Planine Govnjač. Opazna je manjša količina padavin proti vzhodnemu delu grebena. Največje količine na grebenu so ocenjene na 1400-1600 mm. Če vzamemo vmesno količino $1500 \mathrm{~mm}$, to pomeni okrog $200 \%$ več od izmerjenih padavin na postaji Vogel in okrog $140 \%$ korigirane količine na Voglu (če na tej postaji upoštevamo korekcijski faktor 1,56).

Za zanesljivejšo sliko padavin na Bohinjskem grebenu bi potrebovali bolj gosto mrežo meritev. Tudi korekcijski faktorji med dežemeri in vodnatostjo snežne odeje so pozimi še velika neznanka. V tej raziskavi smo vzeli faktor 1,56 za postajo Vogel, kajti dejanskega faktorja za zimo 2005/2006 nismo posebej ugotavljali. Če bi vzeli enak faktor tudi za nižje ležeče postaje (tudi na južni strani grebena), bi močno precenili količino padavin, kajti napake ombrometrov so v nižjih legah zaradi manjše vetrovnosti precej manjše. Kljub tej pomanjkljivosti pa je ta raziskava potrdila ugotovitve predhodnih, da so padavinske akumulacije na grebenu bistveno večje od tistih na postaji Vogel. Po naši oceni je v zimi 2005/2006 znašal ta prirast okoli $40 \%$.

\section{Sklep}

Pokazalo se je, da je snežna odeja sposobna vpiti velik del lastne snežnice in, kadar dežuje, tudi deževnice. Debelejša kot je snežna odeja in manj kot je predelana, več vode lahko vpije. V Dolini je v enodnevni odjugi 3. decembra 2005 približno meter debela snežna odeja vpila $38 \mathrm{~mm}$ vodne iz snega in dežja, tako da ta voda ni prodrla do tal in masne izgube v snežni odeji ni bilo. Vodnatost snežne odeje se je povečala, njeno sesedanje na višino $63 \mathrm{~cm}$ pa je marsikomu vlilo lažno prepričanje, da je voda iz snega odtekla in da so snežne obtežbe manjše od dejanskih. Dokaz za to so velika vodnatost snežne odeje in poškodbe na strehi mejnega prehoda v Ratečah.

Vodnatost snežne odeje je primeren pokazatelj količine padavin v gorskem svetu, kjer je merjenje padavin na način, kot ga poznamo $\mathrm{v}$ nižinah moteno, oteženo in pogosto nezanesljivo. $Z$ metodo enotnega vzorčenja se izognemo napaki, ki nastane zaradi netočnosti vzorčenja vsake plasti posebej (problem robov, izgub in pribitkov v vzorcih, tanke ledene plasti, sipke plasti itd.) $S$ snegom bogate in manj vetrovne zime so zelo primerne za tovrstne raziskave, saj je snežna odeja precej bolj enotna. Nikakor pa to ne velja za suhe in mrzle zime, ko $\mathrm{v}$ gorah pogosto pihajo vetrovi severnega kvadranta. Obilo sonca in prenašanje snega v zamete ustvarijo zelo neenakomerne snežne razmere glede na ekspozicijo in naklon pobočij, več pa je tudi ledenih plasti.

Padavinske razmere na Bohinjskem grebenu so še vedno dokaj nepoznane. Dosedanje raziskave so pokazale, da se količina padavin na grebenu bistveno razlikuje od tiste na meteorološki postaji Vogel, ki je edina postaja v sredogorju na tem območju. Faktor povečanja med območjem pod grebenom in njegovim robom je bil v obravnavani zimi okoli $40 \%$, vendar je slabost te raziskave v razmeroma redki mreži meritev.

Ne glede na uveljavljeno navado, da količino snega opisujemo s podatki o njegovi višini, je vodnatost snežne odeje precej bolj uporaben podatek, ki pove, kakšne so snežne obtežbe in tudi, kako intenzivno 
bo taljenje snega ob daljših odjugah. Ko deževnica, ki jo zadrži sneg v svojih plasteh zmrzne, predstavlja pribitek mase, ki jo je v procesu taljenja snežne odeje potrebno staliti.

\section{Literatura}

Glej angleški del prispevka. 